\title{
REVIEW
}

\section{Dissolved organic nitrogen: a dynamic participant in aquatic ecosystems}

\author{
Tom Berman ${ }^{1, *}$, Deborah A. Bronk ${ }^{2}$ \\ ${ }^{1}$ Yigal Alon Kinneret Limnological Laboratory, Israel Oceanographic and Limnological Research, PO Box 447, \\ Migdal 14950, Israel \\ ${ }^{2}$ College of William and Mary/Virginia Institute of Marine Science, Route 1208, Greate Road, Gloucester Point, \\ Virginia 23062, USA
}

\begin{abstract}
In both marine and freshwaters, the concentration of dissolved organic nitrogen (DON) frequently exceeds that of dissolved inorganic nitrogen (DIN), including ammonium, nitrate, and nitrite. Recent evidence indicates that many organic N compounds are released into the DON pool and taken up from this pool by planktonic microbiota on timescales of hours to days. This observation suggests that many components of the DON pool can play an active role in supplying $\mathrm{N}$ nutrition directly or indirectly to phytoplankton and bacteria and, in so doing, may affect the species composition of the ambient microbial assemblage. Here we present an overview of the state of knowledge of DON pools in aquatic environments, focused mainly on data gathered in the last decade. We review information on DON concentrations in freshwater and marine systems, analytical methods for the determination of DON, and the biotic and abiotic sources and sinks of DON. More detailed discussion addresses specific components of the DON pool: urea, dissolved combined and free amino acids, proteins, nucleic acids, amino sugars, and humic substances. The DON pool in natural waters is not inert and can be an important sink and source for $\mathrm{N}$. There is a need for greater appreciation and understanding of the potential role of DON as a dynamic participant in the nitrogen cycle within aquatic ecosystems, particularly in freshwater environments.
\end{abstract}

KEY WORDS: Dissolved organic nitrogen - Phytoplankton · Bacteria $~ N$ nutrition $\cdot \mathrm{N}$ cycling Marine/freshwater ecosystems

Resale or republication not permitted without written consent of the publisher

\section{INTRODUCTION}

Over 20 yr ago, Antia et al. (1980) wrote: 'we urge oceanographers and marine biologists to stop ignoring the role of dissolved organic nitrogen (DON) in primary production'. Since then, many studies have examined various aspects of DON, both in marine and freshwaters. As a result, the DON pool is increasingly recognized as a dynamic component of the nitrogen $(\mathrm{N})$ and carbon (C) cycles of marine and aquatic systems.

Historically, DON was believed to be composed mainly of refractory compounds resistant to biological degradation and generally unavailable as sources of $\mathrm{N}$ nutrition for phytoplankton or bacteria. Nevertheless, there were several early reports of relatively rapid turnover and high flux rates of total DON pools. Turnover times for total DON and for 'labile' DON in the coastal waters of Southern California were estimated as 21 and $17 \mathrm{~d}$ respectively; these rates were 13 to 14 times more rapid than DON turnover times in the Central North Pacific Gyre (Jackson \& Williams 1985). In Castle Lake, Zehr et al. (1988) reported fast rates of increase in the DON pool in early summer $(0.31 \mu \mathrm{M} \mathrm{N}$ $\mathrm{d}^{-1}$ ). In the photic layer of Lake Kizaki, Japan, Takahashi \& Saijo (1981) measured daily decomposition rates of DON to be $8.6 \%$, implying a DON pool turnover of about $12 \mathrm{~d}$ (Takahashi 2001). Twenty years later, Haga et al. (2001) determined DON residence times in Lake Kizaki ranging from 1.4 to 21 d during May through December, when DON concentrations 


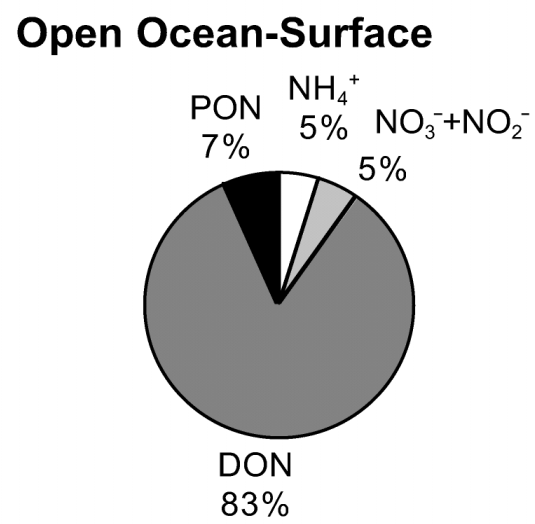

\section{Open Ocean-Deep}

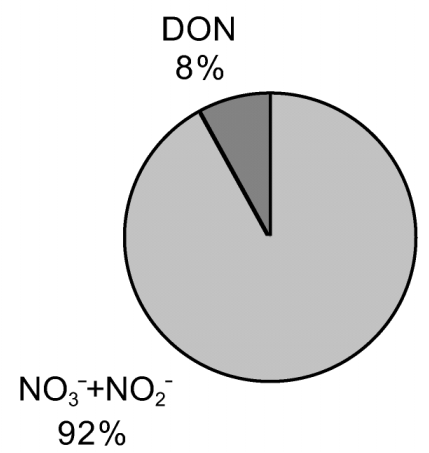

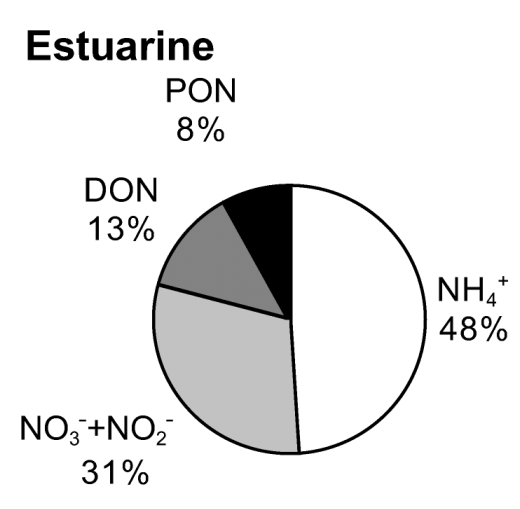

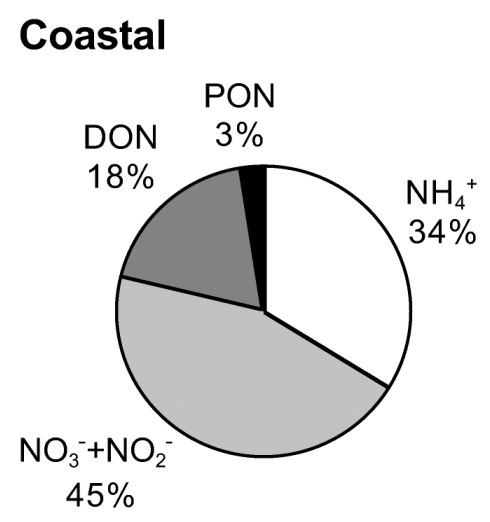

Fig. 1. Average composition of nitrogen pools (except dissolved $\mathrm{N}_{2}$ ) in open ocean surface water, open ocean deep water, coastal and estuarine waters (modified from Antia et al. 1991). DON: dissolved organic nitrogen; PON: particulate organic nitrogen

Fuhrman 2000) and perhaps even protists (Tranvik et al. 1993) have been shown to exploit various components of the DON pool either directly or after bacterial degradation. The potential of photochemical modification or degradation of DON constituents has also been recognized (Bushaw et al. 1996, Moran \& Zepp 2000, Morell \& Corredor 2001).

The capacity of some algal species to exploit DON compounds as sources of $\mathrm{N}$ has led to the idea that specific DON components can exert selective pressure on the composition of the phytoplankton community (Paerl 1997, Seitzinger \& Sanders 1997 , Berman \& Chava 1999). For example, inputs of DON from rivers heavily impacted by human activity may stimulate eutrophication processes and the proliferation of toxic phytoplankton in estuarine and coastal waters (Granéli et al. 1985, Berg et al. 2001).

In this paper we present an overview of the present state of knowledge of DON in both freshwater and marine environments, focusing mainly on information gathered since the extensive review on this topic by Antia et al. (1991). Recently, a comprehensive review focusing on DON dynamics in

ranged from 3.5 to $10.4 \mu \mathrm{M}$ N. Such observations are not consistent with the perception of a DON pool composed entirely of recalcitrant compounds.

Subsequent to the comprehensive and detailed review of Antia et al. (1991), some salient new features of $\mathrm{N}$ flux into and out of DON pools have become evident. These imply that many DON compounds are cycled more rapidly in aquatic environments than previously recognized. We now know that DON may be released from actively growing phytoplankton, sometimes in appreciable quantities (Bronk et al. 1994, Bronk \& Ward 1999, Diaz \& Raimbault 2000), possibly via viral lysis or autolysis of bacteria (Fuhrman 1999) and algae (Gobler et al. 1997, Agusti et al. 1998), that elevated concentrations of DON are common in blooms of Trichodesmium, the primary $\mathrm{N}_{2}$ fixer in the ocean (Capone et al. 1994, Glibert \& Bronk 1994, Vidal et al. 1999), and that atmospheric inputs of DON to the oceans can be substantial (Cornell et al. 1995, Scudlark et al. 1998).

Sinks for DON have also been studied in more detail over the last decade. Algae (Lewitus et al. 2000), cyanobacteria (Berman 2001), bacteria (Antia et al. 1991, Bronk 2002), archaebacteria (Ouverney \& marine systems, though not freshwater environments, was published by Bronk (2002).

\section{CONSTITUENTS OF THE DON POOL}

A considerable proportion of the total $\mathrm{N}$ (TN) pool (excluding dissolved gaseous $\mathrm{N}_{2}$ ) in many freshwater, marine, coastal, and estuarine environments is frequently associated with the DON fraction. Indeed, in many natural waters, concentrations of DON are much higher than those of the total dissolved inorganic nitrogen (DIN) fraction, consisting of ammonium $\left(\mathrm{NH}_{4}^{+}\right)$, nitrate $\left(\mathrm{NO}_{3}{ }^{-}\right)$, and nitrite $\left(\mathrm{NO}_{2}^{-}\right)$. 'Average' composition for seawater total dissolved $\mathrm{N}$ (TDN) pools is shown in Fig. 1. In the deep ocean, however, DON is a small percentage of TDN.

In freshwaters, the DON fraction often exceeds $50 \%$ of the TDN pool and is usually 5 to 10 times higher in concentration than the particulate organic nitrogen (PON) within plankton and seston (Krupka 1989, Wetzel 2001). An example of seasonal data from Lake Kinneret is shown in Fig. 2 (T. Berman \& A. Nishri 


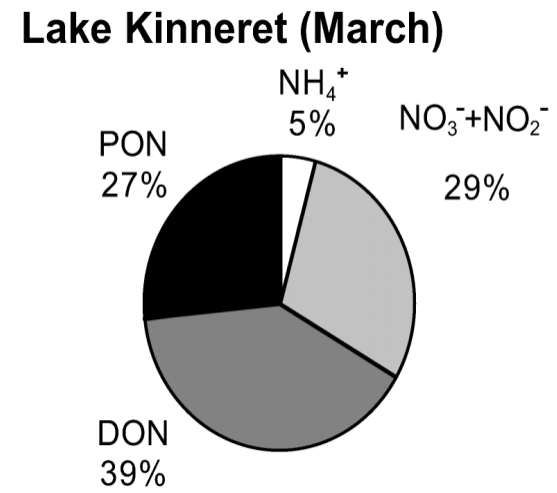

\section{Lake Kinneret (Sept.)}

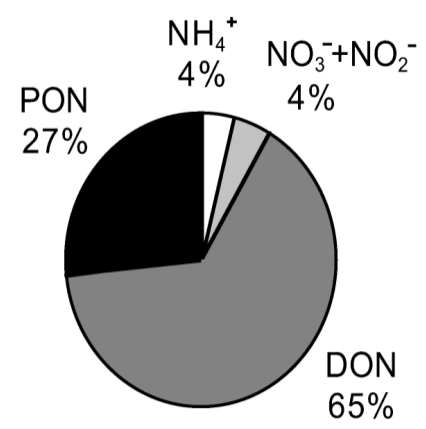

Fig. 2. The distributions of $\mathrm{N}$ fractions in the euphotic zone of a monomictic, meso-eutrophic lake (Lake Kinneret). Values are averaged from 1975 through 1994 for a homothermic period, late winter (March), and a stratified period (September; unpubl. data from Kinneret Laboratory database). DON: dissolved organic nitrogen; PON: particulate organic nitrogen

unpubl. data). The DON:PON ratio tends to decrease as lakes become more eutrophic (Wetzel 2001). A detailed summary of the ranges of DON concentrations in marine waters, their global and vertical distribution, seasonal variation and relationships between DON and DIN is given in Bronk (2002). A condensed version of these data is reproduced in Table 1 together with additional data from freshwater environments. The reader is also directed to Tables $2 \& 3$ in Antia et al. (1991) for details of low molecular weight (LMW) DON compounds, sample locations, and concentrations as reported in the literature prior to 1990.

Much of the DON pool still remains uncharacterized chemically. Operationally, components of the DON pool have been divided into high molecular weight (HMW, usually $>1 \mathrm{kDa}$ ) and LMW compounds. HMW DON includes proteins (such as enzymes, modified bacterial wall proteins, dissolved combined amino acids [DCAA]), nucleic acids (DNA, RNA) and humiclike substances that have a relatively low $\mathrm{N}$ content. There is the added complication that some LMW and HMW DON compounds may be loosely held or adsorbed to humic substances.
Within the last decade the application of ultra-filtration techniques has expanded our knowledge of the HMW DON fraction and added the acronym UDON (ultra-filtered DON) to the literature. Marine HMW DON (i.e. the $>1 \mathrm{kDa}$ fraction) has a characteristic chemical composition that is highly conserved across oceanic regions (McCarthy et al. 1997, 1998). Recent studies of this fraction suggest that much of the refractory DON in the oceans probably consists of amide groups in peptidoglycan remnants enriched with D-enantiomers of alanine, asparagine, glutamic acid, and serine (McCarthy et al. 1996, 1997, 1998, Dittmar et al. 2001, Ogawa et al. 2001). Most of this DON appears to be derived from bacterial cell wall material that has undergone modification of its molecular structure, making it resistant to further degradation. Similar material was present in coastal sediments (Pedersen et al. 2001). To the best of our knowledge, no comparable studies have yet been made in freshwater.

A host of organic nitrogen (ON) compounds make up the LMW DON pool, including urea, peptides (part of the DCAA pool), dissolved free amino acids (DFAA), amino sugars, purines, pyrimidines, pteridines, amides, methyl amides and others (Antia et al. 1991). Many of these compounds may be important $\mathrm{N}$ substrates for autotrophs and heterotrophs (Bronk 2002).

\section{ANALYTICAL METHODS FOR DON DETERMINATION}

A major challenge in the study of DON is the lack of sensitive and precise techniques to quantify total DON concentrations, and those of various known DON constituents. Presently all methods to measure total DON concentrations depend on determining the TDN concentration and then subtracting the separately measured concentrations of DIN (i.e. the sum of $\mathrm{NH}_{4}{ }^{+}, \mathrm{NO}_{3}{ }^{-}$ and $\mathrm{NO}_{2}{ }^{-}$concentrations). This approach combines the analytical errors of 3 analyses: TDN, $\mathrm{NH}_{4}{ }^{+}$and $\left(\mathrm{NO}_{3}{ }^{-}+\right.$ $\mathrm{NO}_{2}^{-}$).

Three basic methods are currently used to obtain the complete oxidation of all the organic constituents of TDN: (1) Variations of the 'wet chemical' method based on persulphate digestion and oxidation to $\mathrm{NO}_{3}{ }^{-}$ (Menzel \& Vaccaro 1964, Sharp 1973, Nydahl 1978, Valderrama 1981, Bronk et al. 2000). Some earlier studies on freshwater used Kjeldahl digestion with $\mathrm{SeO}_{3}$ as the catalyst to determine TDN (Mitamura \& Saijo 1981). (2) Ultraviolet oxidation to $\mathrm{NO}_{3}{ }^{-}$(Armstrong et al. 1966, Armstrong \& Tibbitts 1968, Bronk et al. 2000). (3) High temperature oxidation to NO gas and detection by spectrophotometry (Sharp 1973, Suzuki \& Sugimura 1985), or chemiluminescence (Walsh 1989, Hansell et al. 1993). 
Table 1. Concentrations of total dissolved nitrogen (TDN) and dissolved organic nitrogen (DON) in ocean, coastal, estuarine, riverine, and freshwater systems. Measurement methods were variations of persulfate oxidation (PO), high-temperature oxidation (HTO) or ultraviolet oxidation (UV). HMW: high molecular weight

\begin{tabular}{|c|c|c|c|c|c|}
\hline Location & $\begin{array}{l}\text { Depth } \\
\text { (m) }\end{array}$ & $\begin{array}{c}\text { TDN } \\
(\mu \mathrm{M} \mathrm{N})\end{array}$ & $\begin{array}{c}\text { DON } \\
(\mu \mathrm{M} \mathrm{N})\end{array}$ & Method & Source \\
\hline \multicolumn{6}{|l|}{ Oceanic-surface } \\
\hline Greenland Sea & $<100$ & & $4.6 \pm 0.6$ & $\mathrm{PO}$ & Hubberten et al. (1995) \\
\hline Bering Sea, North Pacific & $<30$ & $8.6 \pm 2.9$ & $2.5 \pm 1.9$ & HTO & Hansell (1993) \\
\hline Western tropical Pacific $\left(10-20^{\circ} \mathrm{S}\right)$ & $<50$ & & $5.4 \pm 0.3^{\mathrm{a}}$ & UV & Hansell \& Feely (2000) \\
\hline Western tropical Pacific $\left(25-35^{\circ} \mathrm{S}\right)$ & $<50$ & & $4.8 \pm 0.4^{\mathrm{a}}$ & UV & Hansell \& Feely (2000) \\
\hline Santa Monica Basin, Pacific & $<100$ & $11.9 \pm 6.2$ & $5.2 \pm 1.9$ & HTO & Hansell et al. (1993) \\
\hline Eastern N. Pacific & $<85$ & $11.1 \pm 6.4$ & $4.1 \pm 0.5$ & $\mathrm{PO}$ & Loh \& Bauer (2000) \\
\hline Subtropical Pacific $\left(5-21^{\circ} \mathrm{N}\right)$ & $<50$ & $5.8 \pm 1.4$ & $5.5 \pm 0.9^{\mathrm{a}}$ & UV & Hansell \& Waterhouse (1997) \\
\hline Equatorial Pacific $\left(6^{\circ} \mathrm{S}-2^{\circ} \mathrm{N}\right)$ & $<50$ & $16.0 \pm 6.1$ & $5.0 \pm 0.7^{\mathrm{a}}$ & UV & Hansell \& Waterhouse (1997) \\
\hline Equatorial Pacific & $<40$ & $13.9 \pm 4.0$ & $8.4 \pm 1.0^{\mathrm{a}, \mathrm{b}}$ & $\mathrm{PO}$ & Libby \& Wheeler (1997) \\
\hline Equatorial Pacific $\left(6-15^{\circ} \mathrm{S}\right)$ & $<100$ & $7.9 \pm 3.5$ & $5.5 \pm 0.7^{\mathrm{a}}$ & UV & Hansell \& Waterhouse (1997) \\
\hline Subtropical Pacific $\left(16-35^{\circ} \mathrm{S}\right)$ & $<150$ & $4.8 \pm 0.4$ & $4.5 \pm 0.4^{\mathrm{a}}$ & UV & Hansell \& Waterhouse (1997) \\
\hline Subpolar Pacific $\left(35-64^{\circ} \mathrm{S}\right)$ & $<150$ & $18.3 \pm 6.8$ & $4.3 \pm 0.6^{\mathrm{a}}$ & UV & Hansell \& Waterhouse (1997) \\
\hline Pacific Equatorial Transition & $<50$ & $5.8-6.0$ & $5.7-5.9^{\mathrm{a}}$ & UV & Abell et al. (2000) \\
\hline Pacific Subtropical Gyre & $<50$ & $5.3-6.3$ & $5.2-6.2^{\mathrm{a}}$ & UV & Abell et al. (2000) \\
\hline Pacific Subtropical Transition & $<50$ & $4.7-5.5$ & $4.5-5.3^{\mathrm{a}}$ & UV & Abell et al. (2000) \\
\hline Equatorial Pacific $\left(16^{\circ} \mathrm{S}-1^{\circ} \mathrm{N}\right)$ & $<200$ & & $\sim 3.0-7.0$ & $\mathrm{PO}$ & Raimbault et al. (1999) \\
\hline Southern California Bight (offshore) & $<55$ & $9.7 \pm 2.4$ & $7.0 \pm 0.4$ & UV & Ward \& Bronk (2001) \\
\hline Southern California Bight (offshore) & $<43$ & $10.8 \pm 5.8$ & $6.6 \pm 1.4$ & UV & Ward \& Bronk (2001) \\
\hline Southern Ocean Polar Front & $<200$ & & $6.9-11.0$ & HTO & Kähler et al. (1997) \\
\hline North of Antarctic Peninsula & Surface & & $0.8-6.3$ & UV & Karl et al. (1996) \\
\hline Pacific Subarctic Frontal & $<50$ & $5.3-7.9$ & $5.1-5.2^{\mathrm{a}}$ & UV & Abell et al. (2000) \\
\hline Southern Ocean & $<150$ & $31.2 \pm 3.1$ & $4.6 \pm 1.5$ & HTO & Ogawa et al. (1999) \\
\hline Southern Ocean (Stn F) & $<94$ & $20.9 \pm 1.1$ & $4.2 \pm 0.2$ & PO & Loh \& Bauer (2000) \\
\hline Ross Sea Polynya & $<150$ & & $2.1-6.3$ & UV & Carlson et al. (2000) \\
\hline Antarctic waters & $<100$ & & $3.9 \pm 1.3$ & $\mathrm{PO}$ & Hubberten et al. (1995) \\
\hline Drake Passage $\left(61-50^{\circ} \mathrm{S}\right)$ & $<50$ & & $3.1-7.3$ & UV & Sanders \& Jickells (2000) \\
\hline North Atlantic $\left(33-60^{\circ} \mathrm{N}\right)$ & Surface & & $4.4-7.4$ & HTO & Kähler \& Koeve (2001) \\
\hline Arctic Ocean (shelf) & $<55^{\mathrm{c}}$ & & $3.6 \pm 0.7$ & $\mathrm{PO}$ & Wheeler et al. (1997) \\
\hline Arctic Ocean (slope) & $<100^{\mathrm{c}}$ & & $5.2 \pm 1.6$ & $\mathrm{PO}$ & Wheeler et al. (1997) \\
\hline Arctic Ocean (basin) & $<100^{\mathrm{c}}$ & & $5.3 \pm 1.4$ & $\mathrm{PO}$ & Wheeler et al. (1997) \\
\hline Sargasso Sea & Surface & & $5.8 \pm 0.8^{\mathrm{a}, \mathrm{b}}$ & UV & Bates \& Hansell (1999) \\
\hline Sargasso Sea (BATS) & Surface & & $4.0-5.5$ & UV & Hansell \& Carlson (2001) \\
\hline Equatorial Atlantic & $<100$ & & $8.2 \pm 4.8$ & $\mathrm{PO}$ & Vidal et al. (1999) \\
\hline Pacific $(\text { HMW DON }>1 \mathrm{kDa})^{\mathrm{d}}$ & $<100$ & & $1.2 \pm 0.2$ & UV & Benner et al. (1997) \\
\hline Atlantic (HMW DON >1 kDa) ${ }^{\mathrm{d}}$ & Surface & & 1.0 & UV & Benner et al. (1997) \\
\hline Gulf of Mexico (HMW DON $>1 \mathrm{kDa})^{\mathrm{d}}$ & 10 & & 1.2 & UV & Benner et al. (1997) \\
\hline Sargasso Sea & Surface & & $5.8 \pm 0.8^{\mathrm{a}, \mathrm{b}}$ & UV & Bates \& Hansell (1999) \\
\hline Sargasso Sea (BATS) & Surface & & $4.0-5.5$ & UV & Hansell \& Carlson (2001) \\
\hline Equatorial Atlantic & $<100$ & & $8.2 \pm 4.8$ & $\mathrm{PO}$ & Vidal et al. (1999) \\
\hline \multicolumn{6}{|l|}{ Oceanic-deep } \\
\hline NE Pacific & $>150$ & $4.82^{\mathrm{e}}$ & $4.5 \pm 0.4$ & UV & Harrison et al. (1992) \\
\hline Greenland Sea & $>100$ & & $3.5 \pm 0.8$ & $\mathrm{PO}$ & Hubberten et al. (1995) \\
\hline Santa Monica Basin & $110-800$ & $36.7 \pm 5.7$ & $4.3 \pm 1.2$ & HTO & Hansell et al. (1993) \\
\hline Subtropical Pacific $\left(5-21^{\circ} \mathrm{N}\right)$ & $51-1000$ & $36.9 \pm 5.7$ & $2.7 \pm 0.7^{\mathrm{a}}$ & UV & Hansell \& Waterhouse (1997) \\
\hline Equatorial Pacific $\left(6^{\circ} \mathrm{S}-2^{\circ} \mathrm{N}\right)$ & $51-1000$ & $38.8 \pm 4.1$ & $2.6 \pm 0.6^{\mathrm{a}}$ & UV & Hansell \& Waterhouse (1997) \\
\hline Equatorial Pacific $\left(6-15^{\circ} \mathrm{S}\right)$ & $101-3000$ & $37.1 \pm 7.1$ & $2.9 \pm 0.8^{\mathrm{a}}$ & UV & Hansell \& Waterhouse (1997) \\
\hline Subtropical Pacific $\left(16-35^{\circ} \mathrm{S}\right)$ & $151-3000$ & $28.3 \pm 12.2$ & $3.0 \pm 0.6^{\mathrm{a}}$ & UV & Hansell \& Waterhouse (1997) \\
\hline Subpolar Pacific $\left(35-64^{\circ} \mathrm{S}\right)$ & $151-3250$ & $31.2 \pm 4.7$ & $2.8 \pm 0.6^{\mathrm{a}}$ & UV & Hansell \& Waterhouse (1997) \\
\hline Pacific Equatorial Transition & $\sim 205$ & & 2.8 & UV & Abell et al. (2000) \\
\hline Pacific Subtropical Gyre & $\sim 305$ & & $2.8-3.7$ & UV & Abell et al. (2000) \\
\hline Pacific Subtropical Transition & $\sim 185$ & & 4.4 & UV & Abell et al. (2000) \\
\hline Pacific Subarctic Frontal & $\sim 145$ & & 3.7 & UV & Abell et al. (2000) \\
\hline Eastern N. Pacific & $100-4097$ & $39.0 \pm 5.2$ & $2.4 \pm 0.4$ & $\mathrm{PO}$ & Loh \& Bauer (2000) \\
\hline Southern Ocean Polar Front & $200-1500$ & & $7.9-9.8$ & НTO & Kähler et al. (1997) \\
\hline Southern Ocean & $\sim 100-4150$ & $36.1 \pm 2.0$ & $3.9 \pm 1.1$ & НTO & Ogawa et al. (1999) \\
\hline Southern Ocean (Stn F) & $142-5408$ & $32.2 \pm 5.4$ & $3.5 \pm 0.6$ & $\mathrm{PO}$ & Loh \& Bauer (2000) \\
\hline Ross Sea Polynya & $150-600$ & & $2.4 \pm 0.3$ & UV & Carlson et al. (2000) \\
\hline
\end{tabular}


Table 1 (continued)

\begin{tabular}{|c|c|c|c|c|c|}
\hline Location & $\begin{array}{l}\text { Depth } \\
\text { (m) }\end{array}$ & $\begin{array}{c}\text { TDN } \\
(\mu \mathrm{M} N)\end{array}$ & $\begin{array}{c}\text { DON } \\
(\mu \mathrm{M} \mathrm{N})\end{array}$ & Method & Source \\
\hline \multicolumn{6}{|l|}{ Oceanic-deep (continued) } \\
\hline Antarctic waters & $>100$ & & $3.0 \pm 1.1$ & $\mathrm{PO}$ & Hubberten et al. (1995) \\
\hline Sargasso Sea (BATS) & $250-1000$ & & $2.1-5.0$ & UV & Hansell \& Carlson (2001) \\
\hline Sargasso Sea (BATS) & $1000-4000$ & & $3.1 \pm 0.4$ & UV & Hansell \& Carlson (2001) \\
\hline Drake Passage $\left(61-50^{\circ} \mathrm{S}\right)$ & $>50$ & & $1.4-2.9$ & UV & Sanders \& Jickells (2000) \\
\hline Equatorial Atlantic & $110-1000$ & & $6.7 \pm 4.1$ & $\mathrm{PO}$ & Vidal et al. (1999) \\
\hline HMW DON >1 kDa ${ }^{\mathrm{d}}$ & $200-2400$ & & $0.5-0.56$ & UV & Benner et al. (1997) \\
\hline \multicolumn{6}{|l|}{ Coastal/Continental shelf } \\
\hline Gulf of Mexico (Los Angeles-Texas coast) & Surface & & $1.9-52.5$ & HTO & López-Veneroni \& Cifuentes (1994) \\
\hline Gulf of Riga, Baltic Sea & Surface & $26.7-29.4^{\mathrm{f}}$ & $18.0-26.4$ & $\mathrm{PO}$ & Tamminen \& Seppällä (1999) \\
\hline Gulf of Riga, Baltic Sea & $2.5-30$ & $15.5-40.2$ & $5.4-23.0^{\mathrm{g}}$ & HTO & Jørgensen et al. (1999) \\
\hline Georges Bank & Surface & & $4.8-5.4$ & UV & Hopkinson et al. (1997) \\
\hline Georges Bank & $200-1500$ & & $2.5-3.4$ & UV & Hopkinson et al. (1997) \\
\hline Middle Atlantic Bight & Surface & & $7.4 \pm 1.1^{\mathrm{a}, \mathrm{b}}$ & UV & Bates \& Hansell (1999) \\
\hline Monterey Bay & $<100$ & $18.5 \pm 6.1$ & $1.9 \pm 1.6$ & HTO & Hansell (1993) \\
\hline Bering Sea, North Pacific & $<30$ & $8.6 \pm 2.9$ & $2.5 \pm 1.9$ & HTO & Hansell (1993) \\
\hline Monterey Bay & $<20$ & $6.5 \pm 1.9$ & $5.2 \pm 1.8$ & $\mathrm{PO}$ & Bronk \& Ward (1999) \\
\hline Northeast Greenland Shelf & $<70$ & 7.2 & $5.9^{\mathrm{h}}$ & $\mathrm{PO}$ & Daly et al. (1999) \\
\hline Akkeshi Bay, Japan & Surface & $7.7 \pm 2.3$ & $6.7 \pm 1.0$ & $\mathrm{PO}$ & Hasagawa et al. (2000a) \\
\hline Japanese bays (2) & Surface & $12.0 \pm 1.6$ & $8.7 \pm 1.6$ & HTO & Tupas \& Koike (1990) \\
\hline Southern California Bight (nearshore) & $<55$ & $10.2 \pm 2.5$ & $7.7 \pm 1.3$ & UV & Ward \& Bronk (2001) \\
\hline \multicolumn{6}{|l|}{ Estuarine } \\
\hline Shinnecock Bay, New York & Surface & $2.0-4.9$ & $0.6-4.3^{\mathrm{i}}$ & $\mathrm{PO}$ & Berg et al. (1997), Lomas et al. (1996) \\
\hline Waquoit Bay, Massachusetts & Surface & 140 & 40.0 & NG & Hopkinson et al. (1998) \\
\hline Chesapeake Bay, mesohaline & Surface & $34.1 \pm 12.3$ & $21.3 \pm 16.0$ & $\mathrm{PO}$ & Bronk et al. (1998) \\
\hline Chesapeake Bay, mesohaline & Surface & $42.5 \pm 3.7$ & $22.3 \pm 9.2$ & $\mathrm{PO}$ & Bronk \& Glibert (1993a) \\
\hline Chesapeake Bay, mesohaline & Surface & $23.1 \pm 1.7$ & $22.2 \pm 1.6$ & $\mathrm{PO}$ & Bronk \& Glibert (1993a) \\
\hline Chesapeake Bay, mouth & Surface & & $16.3 \pm 5.5^{\mathrm{b}}$ & UV & Bates \& Hansell (1999) \\
\hline Apalachicola Bay & Surface & 23 & $14.8 \pm 1.0$ & $\mathrm{PO}$ & Mortazavi et al. (2000) \\
\hline Delaware Estuary & Surface & & $40.8 \pm 29.3$ & $\mathrm{PO}$ & Karl (1993) \\
\hline Elbe Estuary & Surface & $72.2 \pm 17.6$ & $65.0 \pm 12.2$ & $\mathrm{PO}$ & Kerner \& Spitzy (2001) \\
\hline North Inlet, South Carolina & Surface & $19.4-35.3$ & $18.0-30.8$ & NG & Lewitus et al. (2000) \\
\hline Tomales Bay & Surface & & $5.8-12.6$ & UV & Smith et al. (1991) \\
\hline \multicolumn{6}{|l|}{ Rivers } \\
\hline Russian rivers draining into Arctic (7) & Surface & & $27.0 \pm 5.0$ & NG & Gordeev et al. (1996), Wheeler et al. (1997) \\
\hline Rivers entering the Baltic Sea (5) & Surface & $48.9 \pm 41.9$ & $29.8 \pm 14.8$ & HTO & Stepanauskas et al. (2002) \\
\hline Susquehanna River, Maryland & Surface & 116 & 23.0 & NG & Hopkinson et al. (1998) \\
\hline Satilla River, Georgia & Surface & 62.6 & 59.0 & NG & Hopkinson et al. (1998) \\
\hline Parker River, Maryland & Surface & 37 & 26.0 & NG & Hopkinson et al. (1998) \\
\hline Delaware River & Surface & & $29.7 \pm 23.7$ & HTO & Seitzinger \& Sanders (1997) \\
\hline Hudson River & Surface & & 33.5 & HTO & Seitzinger \& Sanders (1997) \\
\hline Rivers in USA and Europe (17) & Surface & & & NG & Seitzinger \& Sanders (1997) \\
\hline Choptank River & Surface & 41.3 & 26.9 & $\mathrm{PO}$ & Bronk \& Glibert (1993a) \\
\hline Georgia and South Carolina Rivers $(8)^{\mathrm{j}}$ & Surface & & $35.9 \pm 10.7$ & NG & Alberts \& Takács (1999) \\
\hline Streams in Sweden $(2)^{\mathrm{k}}$ & Surface & & $24.3 \pm 7.4$ & HTO & Stepanauskas et al. (2000) \\
\hline Wetland in Sweden (bulk DON) ${ }^{1}$ & Surface & & $90.0 \pm 68.0$ & $\mathrm{PO}$ & Stepanauskas et al. (1999b) \\
\hline Lagunitas Creek (flows to Tomales Bay) & Surface & & $3.9-17.9$ & UV & Smith et al. (1991) \\
\hline \multicolumn{6}{|l|}{ Lakes } \\
\hline Mendota, USA & $0 \mathrm{~m}$ & 42.3 & 44.7 & NG & Wetzel (2001) \\
\hline Mendota, USA & $20 \mathrm{~m}$ & & 44.2 & NG & Wetzel (2001) \\
\hline Fureso, Denmark & & & $31.4-45.7$ & NG & Wetzel (2001) \\
\hline Ysel, Netherlands & & & $42.1-131.4$ & NG & Wetzel (2001) \\
\hline Constance, Germany & & & $3.6-10.7$ & NG & Wetzel (2001) \\
\hline Lucerne, Switzerland & & & $5.7-12.9$ & NG & Wetzel (2001) \\
\hline Rotsee, Switzerland & & & $19.2-47.1$ & NG & Wetzel (2001) \\
\hline Wintergreen, USA & & & $35.7-94.3$ & NG & Wetzel (2001) \\
\hline Lawrence, USA & & & $5.7-17.1$ & NG & Wetzel (2001) \\
\hline Kizaki, Japan & & $15.9-24.0$ & $4.8-12.5$ & $\mathrm{PO}$ & Takahashi \& Saijo (1981) \\
\hline Biwa, Japan N Basin & & $7.0-8.0$ & $4.0-7.2$ & $\mathrm{PO}$ & Mitamura \& Matsumoto (1981) \\
\hline
\end{tabular}


Table 1 (continued)

\begin{tabular}{|c|c|c|c|c|c|}
\hline Location & $\begin{array}{l}\text { Depth } \\
(\mathrm{m})\end{array}$ & $\begin{array}{c}\mathrm{TDN} \\
(\mu \mathrm{M} \mathrm{N})\end{array}$ & $\begin{array}{c}\mathrm{DON} \\
(\mu \mathrm{M} \mathrm{N})\end{array}$ & Method & Source \\
\hline \multicolumn{6}{|l|}{ Lakes (continued) } \\
\hline Biwa, Japan S Basin & & $7.0-15.0$ & $5.4-8.6$ & $\mathrm{PO}$ & Mitamura \& Matsumoto (1981) \\
\hline Okeechobee, USA & & 67.6 & $41.2-63.1$ & $\mathrm{PO}$ & Gu et al. (1997) \\
\hline Plüssee, Germany & $0-15$ & $51-104$ & 47.1 & $\mathrm{PO}$ & Münster \& Albrecht (1994) \\
\hline Plüssee, Germany & $20-25$ & $12-259$ & $88.5-187.8$ & $\mathrm{PO}$ & Münster \& Albrecht (1994) \\
\hline Kinneret, Israel-winter & $0-15$ & 47.9 & 26.1 & $\mathrm{PO}$ & Present study \\
\hline Kinneret, Israel-spring & $0-15$ & 25.6 & 22.7 & $\mathrm{PO}$ & Present study \\
\hline \multicolumn{6}{|c|}{ a Data presented are total organic nitrogen (TON) } \\
\hline \multicolumn{6}{|c|}{${ }^{\mathrm{b}} \mathrm{TON}$ includes ammonium } \\
\hline \multirow{2}{*}{\multicolumn{6}{|c|}{$\begin{array}{l}{ }^{\mathrm{c}} \text { Data were converted from } \mathrm{g} \mathrm{m}^{-2} ; \text { mean and } \mathrm{SD} \text { at stations within each area are reported } \\
{ }^{\mathrm{d}} \text { Samples from the Pacific, Atlantic, and Gulf of Mexico }\end{array}$}} \\
\hline & & & 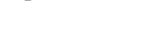 & & \\
\hline \multicolumn{6}{|c|}{ eEstimated from integrated values throughout the upper $150 \mathrm{~m}$} \\
\hline \multicolumn{6}{|c|}{${ }^{\mathrm{f}}$ Sum of the average DON, nitrate and ammonium concentrations } \\
\hline \multicolumn{6}{|c|}{ 'J Jørgensen et al. (1999) listed urea separately; it was added back into the DON pool } \\
\hline \multicolumn{6}{|c|}{ hMedian values } \\
\hline \multicolumn{6}{|c|}{${ }^{\mathrm{i}}$ Measured during a bloom of Aureococcus anophagefferens } \\
\hline \multicolumn{6}{|c|}{ j Averages for 8 rivers (Altamaha, Black, Edsto, Ogeechee-Eden, Ogeechee-Oliver, Peedee, Satilla, Savannah, and St. Mary's) } \\
\hline \multicolumn{6}{|c|}{ k The 2 streams were Lillån and Stridbäcken } \\
\hline${ }^{1}$ The 3 wetlands were An & d Vomb & & & & \\
\hline
\end{tabular}

The need to improve techniques for measuring DON has long been recognized. To this end, a working group was convened in 1993 to decide how best to proceed and to offer recommendations to the oceanographic community (Hopkinson et al. 1993). Other comparisons of DON methodology were subsequently published (Walsh 1989, Williams 1993, Bronk et al. 2000). A recent cross-laboratory exercise with 29 sets of analyses comparing these methods on 5 marine samples gave a coefficient of variation ranging from 19 to $46 \%$, with the poorest replication of samples from deep ocean waters (Sharp et al. 2002). All the methods gave similar levels of sensitivity and precision. We conclude that present methods are reasonably compatible but that new or improved techniques for determining concentrations of DON with better sensitivity and precision are still needed.

\section{SOURCES OF DON}

DON may come from both allochthonous and autochthonous sources. The former includes terrestrial runoff, leaching from plant detritus and soils into streams and rivers, sediments, and atmospheric deposition. Autochthonous sources may include release by exudation from phytoplankton, macrophytes and bacteria, from cell death or viral lysis, or from micro- and macrozooplankton grazing and excretion (Fig. 3).

In the case of streams, rivers, lakes and freshwater reservoirs, much of the DON is often derived from terrestrial leaching and runoff, and consists mainly of humic substances. Significant inputs of DON to shallow freshwaters and wetlands may be derived from active or passive release from submerged macrophytes (Crowder \& Painter 1991) and benthic algae (Jansson 1979). Clearly the composition of DON exported by rivers into lakes, estuaries and coastal waters may be radically different depending on the nature of the catchment areas being drained. In many freshwater systems, anthropogenic sources are responsible for significant inputs of DON that is transported downstream to estuarine and coastal waters (Seitzinger \& Sanders 1997, 1999).

A study by Perakis \& Hedin (2002) found that $70 \%$ of the TDN in streams and rivers of temperate South American forest regions that were pristine and free of human intervention consisted of DON. In contrast, DON comprised only $2 \%$ of the TDN in the running water of a forested area in NE USA. This dramatic difference was attributed to the impact of human activities that have doubled $\mathrm{N}$ input into the global terrestrial cycle within the last century. The consequences have been an atmosphere polluted with $\mathrm{NH}_{4}{ }^{+}$ and $\mathrm{N}$ oxides in heavily industrialized areas, increased atmospheric $\mathrm{N}$ deposition, acidified soils, streams and lakes, decreased biodiversity and impacted coastal ecosystems and fisheries (van Breemen 2002). Paradoxically, despite the low percentage of DON in the TDN of NE USA forest streams measured by Perakis \& Hedin (2002), we note that Alberts \& Takács (1999) estimated that DON accounts for 40 to $90 \%$ of the TDN in rivers of the SE USA. 
The quantities and characteristics of DON in estuarine and marine coastal waters depend on riverine inputs. In coastal zones, terrestrial run-off is also an important factor and the amounts and availability of DON vary depending on the source. Approximately $25 \%$ of DON from 2 pastures and $20 \%$ of DON from a mixed hardwood forest in summer were utilized by freshwater bacteria in short-term bioassays (Wiegner \& Seitzinger 2001). Seitzinger et al. (2002) found that storm water runoff from urban/suburban areas had a higher proportion of bioavailable DON (59 $\pm 11 \%)$ than that from agricultural pastureland (30 $\pm 14 \%)$ and forests $(23 \pm 19 \%)$. Only 8 to $15 \%$ of the bulk DON in a relatively pristine wetland in Sweden was potentially bioavailable to estuarine bacteria (Stepanauskas et al. 1999a,b).

In shallow freshwater, estuarine and coastal systems, sediments can be an important source of DON to the overlying water column (reviewed in Burdige \& Zheng
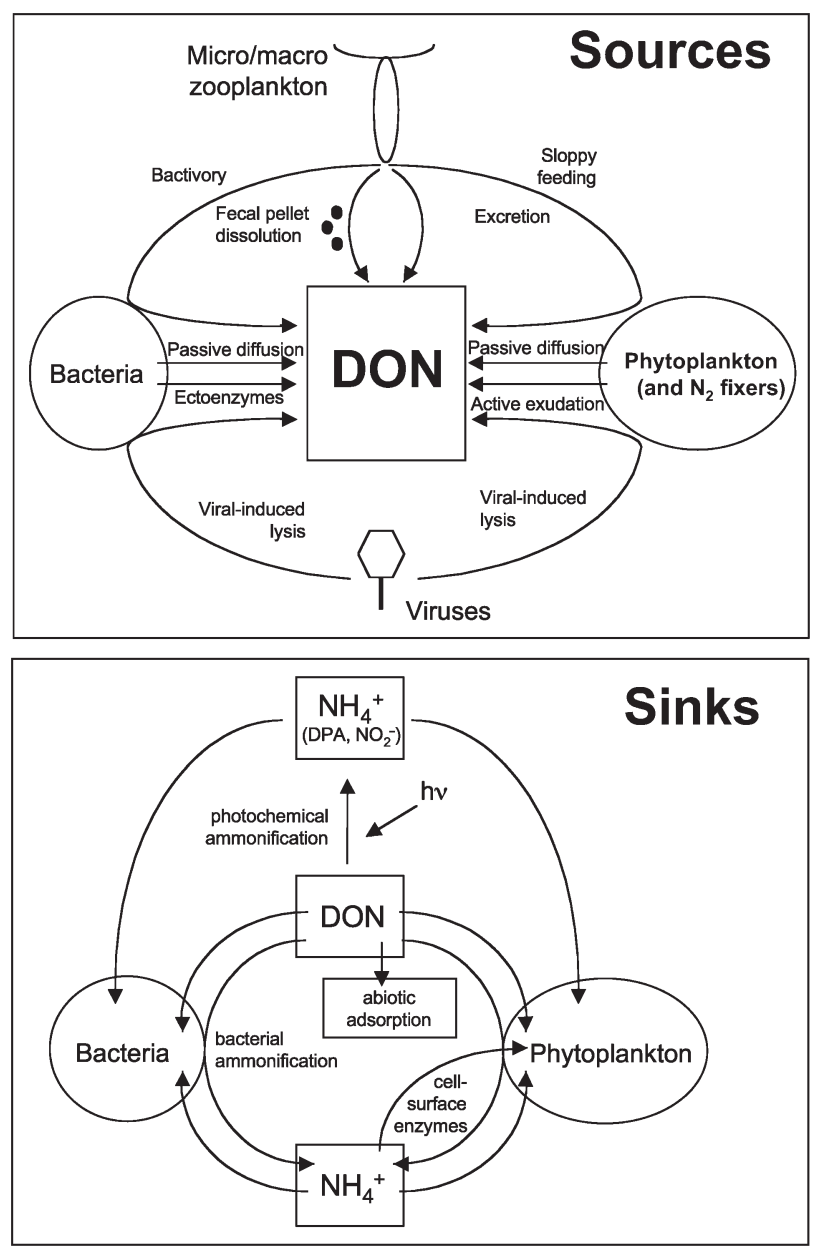

Fig. 3. Sources and sinks of dissolved organic nitrogen (DON) in aquatic systems. DPA stands for dissolved primary amines. Modified from Bronk (2002)
1998). Sediment release was the major source of DON in meso-oligotrophic Castle Lake, California (Zehr et al. 1988) and in shallow Danish coastal waters. Lomstein et al. (1998) estimated that efflux of DON from sediment was about twice that of DIN. In another study of sediment-water $\mathrm{C}$ and $\mathrm{N}$ fluxes at Limfjord, Denmark, Middleboe et al. (1998) also found DON (urea, DFAA and DCAA) to be the dominant $\mathrm{N}$ form released from the sediments. These authors suggested that in many cases the estimates of DON flux were underestimated because rapid bacterial uptake of DON in the overlying water was not taken into account.

Although the importance of atmospheric DON inputs has now become evident both for freshwater and marine systems, few data are available to evaluate these inputs (Shaw et al. 1989, Cornell et al. 1995, 2001, Russell et al. 1998, Scudlark et al. 1998). Cornell et al. (1995) proposed that the atmospheric input of fixed $\mathrm{N}$ to the ocean is about twice that of previous estimates. At continental sites in North America, between 20 and $75 \%$ of the DON in atmospheric deposition has been reported to be bioavailable (Timperley et al. 1985, Peierls \& Paerl 1997, Seitzinger \& Sanders 1999), with urea as an important constituent. However, we note that the quantitative importance of urea in atmospheric deposition is under debate (Cornell et al. 1998). DON from rainwater stimulated growth of marine phytoplankton (Peierls \& Paerl 1997) and of axenic cultures of freshwater algae (Timperley et al. 1985). One study in the NE USA demonstrated that a large percentage ( 45 to $75 \%$ ) of the DON in rainwater was biologically available and stimulated the productivity of coastal marine bacteria and phytoplankton (Seitzinger \& Sanders 1999).

Excretion by waterfowl is an additional exogenous source of DON that may be quite significant in some shallow and small freshwater environments (Manny et al. 1994). This is unlikely, however, to be of much importance in the pelagic ocean!

In the open ocean, autochthonous sources of DON dominate, especially for the more labile constituents of the pool. As noted previously, DON is excreted by living algae (e.g. Bronk \& Ward 1999, Nagao \& Miyazaki 2002) although the actual amounts of DON released are still controversial (Slawyk \& Raimbault 1995, PujoPay et al. 1997, Flynn \& Berry 1999, Nagao \& Miyazaki 1999, Bronk \& Ward 2000, Slawyk et al. 2000). DON is also released when algae lyse, due to viral infection (Bratbak et al. 1998) or by natural cell death (apoptosis), when grazers feed 'sloppily' (Dagg 1974, Jumars et al. 1989), or during zooplankton excretion (Lampert 1978, Riemann et al. 1986, Wiltshire \& Lampert 1999, Rosenstock \& Simon 2001). Protists may release DON compounds as a result of feeding on bacteria, pico- 
plankton or possibly when eaten (Antia et al. 1980, Berman et al. 1987, Hasagawa et al. 2000a,b, 2001, Nagata 2000). Zooplankton and higher trophic level animals may also contribute to DON. For example, in the sea, as contrasted to fresh water, the excretions of animals such as cetaceans, tunicates, teleost and cartilaginous fish may also add to the DON pool. The hydrolytic activity of bacteria and protists associated with macro- and micro-aggregates (Smith et al. 1992, Hoppe et al. 1993, Grossart \& Simon 1998) and transparent proteinaceous particles (Long \& Azam 1996, Berman \& Viner-Mozzini 2001) that are numerous in both marine and freshwater environments may also release DON. Organic N contained within small bacteria and viruses that pass through the 0.45 or $0.2 \mu \mathrm{m}$ pore-size filters generally used to obtain the 'dissolved' water fraction is likely an insignificant fraction of the total DON measured in most routine determinations.

\section{SINKS FOR DON}

The 4 main sinks for DON are bacterial uptake, phytoplankton uptake, photochemical decomposition and abiotic adsorption (Fig. 3).

Degradation as a result of bacterial activity probably accounts for the major flux of $\mathrm{N}$ out of the DON pool in most aquatic systems. Obviously some ON compounds are more labile than others. Many of the intermediate compounds formed (e.g. amino acids from hydrolysis of proteins and peptides, urea from purine breakdown) are taken up and utilized directly by bacteria and phytoplankton. Further breakdown will generate $\mathrm{NH}_{4}{ }^{+}$, which is either assimilated directly by the microbiota or nitrified to $\mathrm{NO}_{3}{ }^{-}$. Berman et al. (1999) showed that $\mathrm{NH}_{4}^{+}$and urea were released from indigenous DON compounds in unamended, $1.0 \mu \mathrm{m}$ filtered marine and freshwaters within several days, presumably as the result of bacterial metabolism.

The ability of some algal species to utilize DON sources such as amino acids and urea has long been known (Pintner \& Provasoli 1963, North \& Stephens 1967, Wheeler et al. 1973, Antia et al. 1975, Neilson \& Larsson 1980). Most of these studies, however, used axenic batch cultures growing on high initial concentrations of ON substrates, thus the ability of organisms to exploit the much lower concentrations of these compounds encountered in the environment in situ is unclear. Nevertheless, it seems reasonable that the utilization of DON by different populations of bacteria and phytoplankton can vary considerably. Berman \& Chava (1999) observed that different assemblages of dominant phytoplankton developed when they incubated Lake Kinneret water with various added ON sources. These authors suggested that the kind of ON substrates available in any given environment could influence the species composition of the phytoplankton. Seitzinger \& Sanders (1999) also noted that the community composition of phytoplankton differed in growth experiments with estuarine water enriched with rainwater DON (diatoms and or dinoflagellates dominant) or with $\mathrm{NH}_{4}^{+}$(small monads dominant). There is also some evidence that inputs of DON to estuarine and coastal waters stimulated the development of brown tide blooms of Aureococcus anophagefferens (Gobler \& Sañudo-Wilhelmy 2001, Gobler et al. 2002). Axenic cultures of $A$. anophagefferens were able to hydrolyze a variety of DON compounds (peptides, chitobiose, acetamide and urea) indicating the ability of this organism to exploit these substrates (Berg et al. 2002).

It now appears that in many situations DON can be an important source of phytoplankton $\mathrm{N}$ nutrition in the natural environment. For example, Benner et al. (1997) estimated that 30 to $50 \%$ of daily phytoplankton $\mathrm{N}$ demand in the equatorial North Pacific could be supplied by remineralization of the DON pool. Brown tides off Long Island usually occur in drought years when $\mathrm{NO}_{3}^{-}$inputs are reduced and DON concentrations are high relative to DIN (LaRoche et al. 1997). DON was found to be the major source of $\mathrm{N}$ for phytoplankton in the Gulf of Riga, Baltic Sea, and may be an important contributing factor to the eutrophication of these waters (Berg et al. 2001). Townsend \& Thomas (2002) present data suggesting that DON provides some of the $\mathrm{N}$ requirement at the start of the winterspring phytoplankton bloom on Georges Bank. In Lake Kinneret, a bloom of the cyanobacterium Aphanizomenon ovalisporum used the DON pool as its major $\mathrm{N}$ source (Berman 1997, 2001). Uptake rates and turnover times for total DON and for some of the major ON constituents in this pool, which have been reported from a variety of marine and freshwater locations, are given in Table 2.

Exposure of dissolved organic matter, in particular humic substances, to sunlight (especially in the UVA and UVB region) results in the photoproduction of biologically available $\mathrm{N}$, including $\mathrm{NH}_{4}{ }^{+}$, dissolved primary amines, and $\mathrm{NO}_{2}^{-}$(Bushaw et al. 1996, Moran \& Zepp 1997, Bushaw-Newton \& Moran 1999, Kieber et al. 1999, reviewed in Bronk 2002). This process has been studied in humic-rich waters from many different locales including boreal ponds in Mannitoba, swamps and an estuary in Georgia (Gao \& Zepp 1998, Bushaw-Newton \& Moran 1999), a Swedish (Jørgensen et al. 1998) and a Venezuelan lake (Gardner et al. 1998), a river and bayou in Louisiana (Wang et al. 2000) and in the Orinoco River plume (Morell \& Corredor 2001). Photochemical release may account for considerable $\mathrm{N}$ flux from 
DON in rivers, near-surface marine waters, and freshwater environments. For example, Bushaw et al. (1996) calculated that the additional input by photo- chemical release from riverine DON into the SE USA coastal waters increased the available, terrestrially derived $\mathrm{N}$ by $20 \%$. Although sunlight was effective in

Table 2. Uptake rates and turnover times of dissolved organic nitrogen (DON) compounds in marine (M) and freshwater (FW) systems. DFAA: dissolved free amino acids

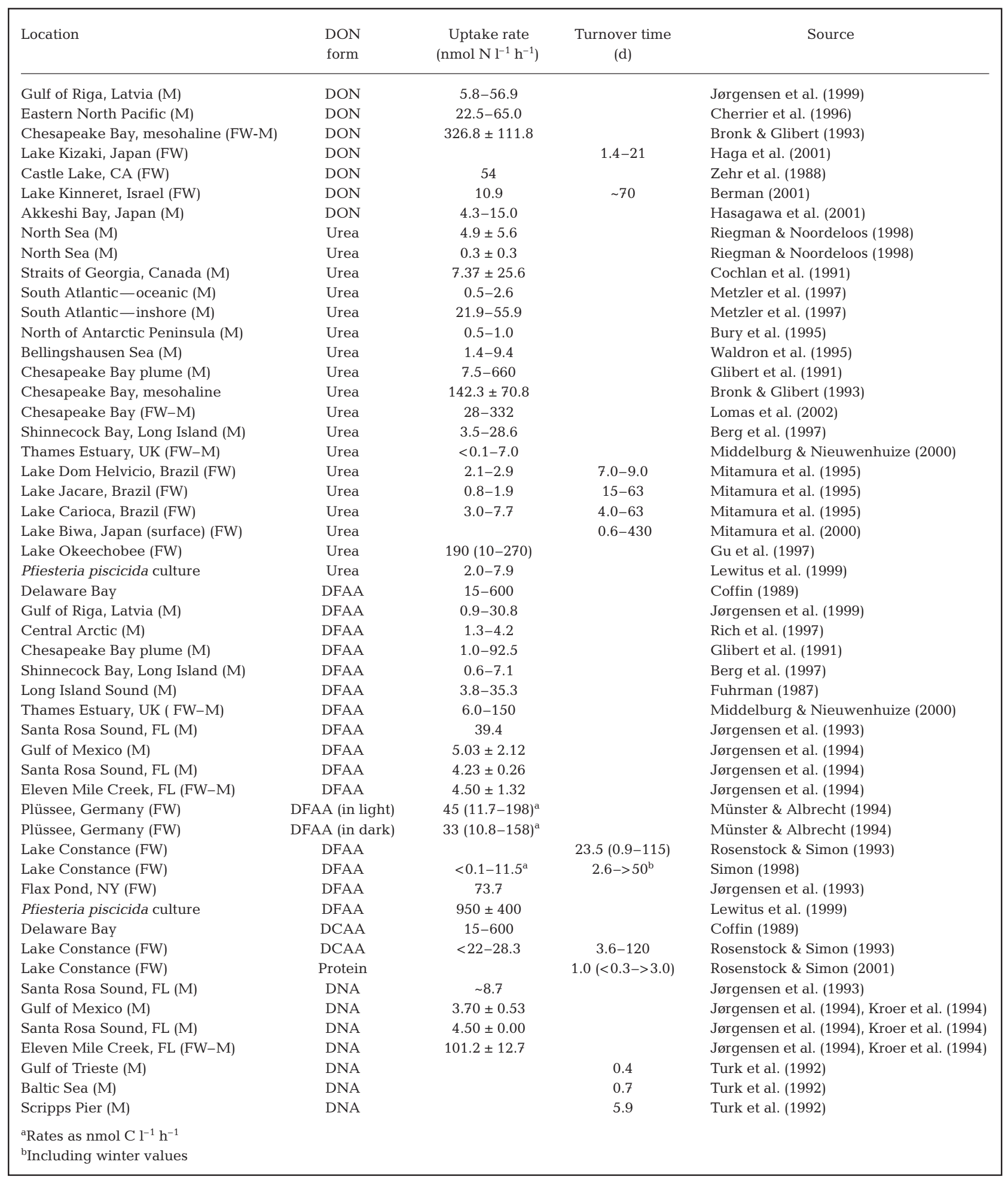


producing $\mathrm{NH}_{4}{ }^{+}$from DON in samples from 2 tidal creeks and the Satilla River, Georgia, USA, this was not the case with surficial $(<10 \mathrm{~m}$ depth) groundwater, suggesting that the ambient concentrations of $\mathrm{NH}_{4}{ }^{+}$and the source of DON were both important factors in determining the impact of irradiation (Koopmans \& Bronk 2002). However, sunlight has also been found to decrease $\mathrm{NH}_{4}{ }^{+}$concentrations (Bertilsson et al. 1999, Wiegner \& Seitzinger 2001) possibly as a result of interactions with the dissolved organic matter pool.

An often neglected 'sink' for components of the DON pool is their removal by adsorption to colloids (Schuster et al. 1998), sub-micron particles (Nagata \& Kirchman 1996), very small particles such as transparent exopolymer particles (TEP; Alldredge et al. 1993) or Coomassie Blue proteinaceous particles (Long \& Azam 1996). Significant quantities of ON compounds, such as amino acids and proteins, may be removed from solution by adsorption to particles, although they remain susceptible to exploitation by particle-associated bacteria and protists.

\section{INDIVIDUAL ORGANIC N COMPOUNDS}

The DON pool is a heterogeneous mixture of compounds that varies widely in space and time within the aquatic environment. The bulk of the ambient DON pool at any given time may consist of compounds that are relatively recalcitrant to biological, chemical or physical degradation, simply because the more labile and biologically available constituents are rapidly broken down and utilized (Gardner et al. 1996).

Below, we discuss some of the better-characterized constituents of the DON pool: urea, DFAA, DCAA and proteins, nucleic acids, amino sugars, and humic substances.

\section{Urea}

There has been some debate whether urea should be included as a component of the DON pool (Jørgensen et al. 1999, Capone 2000). We recommend that urea, the compound that had the distinction of being the accidental product of the 'first organic synthesis' by Wöhler in 1828, should be classified within the DON fraction for the sake of both consistency and continuity. Irrespective of semantics, urea is found ubiquitously in natural waters, sometimes in reasonably high concentrations, and is often a significant source of $\mathrm{N}$ and $\mathrm{C}$ for aquatic microbiota (see below).
Urea assays

Two methods have been used to determine urea concentrations in natural waters: (1) Complexation of urea with diacetyl monoxime to give an imidazolene that forms a red complex with thiosemicarbazide (Newell et al. 1967, Koroleff 1983, Mulvenna \& Savidge 1992, Goeyens et al. 1998). (2) An enzymatic method based on hydrolysis of urea in the presence of added urease and subsequent determination of released $\mathrm{NH}_{4}{ }^{+}$ (McCarthy 1970). A study comparing these 2 techniques indicated that the enzymatic method tended to underestimate urea concentrations because urease activity was inhibited in some samples (Price \& Harrison 1987).

\section{Urea sources}

Urea is produced by water column bacteria (Cho et al. 1996, Therkildsen et al. 1997), excreted by marine and freshwater teleost fish, cetaceans, cryptomonads, herbivorous marine and freshwater zooplankton, bivalve mollusks, freshwater crabs (Antia et al. 1991, Conover \& Gustavson 1999, Wiltshire \& Lampert 1999), protists (Johannes 1965), prawns (Chen \& Cheng 1993), calanoid copepods (Miller \& Glibert 1998) and likely by many other organisms. The degradation of purines and arginine through bacterial action can also give rise to urea (Antia et al. 1991, Berman et al. 1999), and urea may be released into the water column from sediments (Burdige \& Zheng 1998, Thomsen \& Jahmlich 1998). Rainfall, dust and atmospheric aerosols are further sources of urea (Timperley et al. 1985), although a recent study concluded that urea is not always a major DON constituent in wet deposition (Cornell et al. 1998).

Human-derived pollution and runoff from agricultural areas are important additional sources of urea in many lakes, reservoirs, estuaries and coastal waters. Urea accounts for ca. $40 \%$ of the total $\mathrm{N}$ fertilizer used globally (Matthews 1994). For example, long-term studies in Chesapeake Bay have found that external inputs of urea from the watershed are extremely significant in this estuarine system (Lomas et al. 2002).

The highest concentrations of urea in aquatic systems are frequently found at the surface of sediments. However, urea efflux from sediment only accounts for a minor fraction of sediment urea production (Lomstein et al. 1989, Therkildsen \& Lomstein 1994), most of which is mediated by bacteria (Pedersen et al. 1993). Purines and pyrimidines, but not protein, were important substrates for urea generation in an anoxic coastal sediment (Therkildsen et al. 1996). This report would suggest that there is an as yet unknown metabolic 
pathway of urea production from pyrimidines by bacteria in anaerobic sediments. Urea concentrations in Chesapeake Bay were generally higher but more variable in samples taken from $\sim 1 \mathrm{~m}$ above the sediment than in surface samples (Lomas et al. 2002). High concentrations of urea (5.0 to $9.3 \mu \mathrm{M} \mathrm{N}$ ) were also found in the surface films of lake and coastal waters (Saijo et al. 1974).

Although urea generally constitutes only a small percentage of DON in natural waters, it contributed from 60 to $80 \%$ of the $\mathrm{N}$ utilized during much of the year in the plume of Chesapeake Bay, and up to $50 \%$ in many other coastal regions (Harrison et al. 1985, Kokkinakis \& Wheeler 1988, Glibert et al. 1991). We emphasize that the ambient concentrations of urea measured at any given time do not necessarily relate to the actual $\mathrm{N}$ flux passing through the urea pool.

\section{Urea sinks}

The potential importance of urea as a $\mathrm{N}$ source for phytoplankton in a variety of aquatic environments is well documented (McCarthy 1972, Horrigan \& McCarthy 1981, Mitamura \& Matsumoto 1981, McCarthy et al. 1982, Mitamura \& Saijo 1986, Price \& Harrison 1988, Mitamura et al. 1994, 1995, 2000, Glibert et al. 1995, Maguer et al. 1996, Bronk et al. 1998, Shaw et al. 1998, Berman \& Chava 1999). Macrophytes, such as eel grass Zostera capricorni (Hansen et al. 2000), and benthic microbial mats (Rondell et al. 2000) can also use urea as a source of N. Although urea might be considered an 'ideal' $\mathrm{N}$ substrate, the relative preference index of McCarthy et al. (1977) indicates that the sequence of uptake rates in situ is usually $\mathrm{NH}_{4}{ }^{+}>$urea $>\mathrm{NO}_{3}{ }^{-}$. Possibly the small size of the $\mathrm{NH}_{4}{ }^{+}$ ion facilitates its passage across cell membranes while a more energy-expensive, active transport system may be required to move urea into the cell (Price \& Harrison 1988). Another reason for lower urea utilization may be the energetic costs of synthesizing urease needed to hydrolyze this substrate.

Some phytoplankton species show preferential growth with urea as the sole source of $\mathrm{N}$, compared to growth on $\mathrm{NH}_{4}{ }^{+}, \mathrm{NO}_{3}{ }^{-}$or other $\mathrm{ON}$ compounds (Berman \& Chava 1999). There are also intriguing hints that urea may be a major $\mathrm{N}$ source for both marine and freshwater Synechococcus (Berman \& Chava 1999, Collier et al. 1999, Mitamura et al. 2000, Sakamoto \& Bryant 2001) as well as for other cyanobacteria. Preferential uptake by picophytoplankton of urea and $\mathrm{NH}_{4}{ }^{+}$over $\mathrm{NO}_{3}{ }^{-}$was observed in Antarctic surface waters (Probyn 1985), in Lake Biwa (Mitamura \& Saijo 1986, Mitamura et al. 2000), and in 3 Brazilian lakes (Mitamura et al. 1995), where turnover times for urea ranged from 4 to $41 \mathrm{~d}$ during the dry season and 3 to $560 \mathrm{~d}$ during the wet season (Table 2).

Urea was a significant $\mathrm{N}$ source for phytoplankton in reservoirs of the Han River system in Korea and was decomposed more effectively by algae than by bacteria (Mitamura et al. 1989). Studies in estuarine and coastal systems have also found that $\mathrm{N}$ uptake from urea was predominantly by phytoplankton rather than by bacteria (Remsen et al. 1972, Savidge \& Hutley 1977, Savidge \& Johnston 1987, Cho \& Azam 1995, Cho et al. 1996, Tamminen \& Irmisch 1996, Lomas et al. 2002). In contrast, bacterial, rather than phytoplankton, uptake of urea predominated in Finnish coastal waters (Tamminen \& Irmisch 1996), Danish estuarine and coastal waters (Jørgensen et al. 1999), and in the River Thames (Middelburg \& Nieuwenhuize 2000).

Urea may have effects on phytoplankton in addition to serving as a direct source of N. Wiltshire \& Lampert (1999) reported that urea excreted by the freshwater cladoceran Daphnia induced colony formation in the chlorophyte Scenedesmus obliquus.

Bacteria have long been known to mineralize urea, both in the ocean (Cho et al. 1996) and in lakes (Satoh et al. 1980). In Californian coastal waters, urea regeneration rates by bacteria were $\sim 100$-fold greater than for urea uptake (Cho et al. 1996). Temporal differences between production and uptake may account for some of the wide variability often shown in urea concentrations in natural waters (McCarthy 1972, McCarthy \& Kamykowski 1972, Berman 1974). In contrast, other studies have found close coupling between urea production and uptake (Hansell \& Goering 1989, Lomas et al. 2002).

Measurements of urea uptake by phytoplankton and bacteria have generally relied on the use of ${ }^{15} \mathrm{~N}$-tagged substrates. By using simultaneous additions of duallabeled urea $\left({ }^{15} \mathrm{~N}\right.$ and $\left.{ }^{14} \mathrm{C}\right)$, Hansell \& Goering (1989) were able to correct for problems of isotope dilution and thus improve estimates of rates of urea production and uptake by natural phytoplankton in the Bering Sea. Their results indicate that urea is in a dynamic steady state, with rates of in situ urea production approximately equal to consumption. In another study using this technique, Bronk et al. (1998) found that not correcting for urea isotope dilution sometimes resulted in a substantial underestimate of urea uptake rates, and that urea regeneration was generally a small, but highly variable, source of $\mathrm{N}$.

Recently Peers et al. (2000) showed that a constitutive urease activity was present in the marine diatoms Thalassiosira pseudonana and T. weissflogii regardless of $\mathrm{N}$ source. Urease activity in $T$. weissflogii was unaffected by iron limitation but sensitive to that of nickel (Milligan \& Harrison 2000). Nickel is a constituent of 
the active site of algal and cyanobacterial ureases, and has been shown to be an essential micronutrient for urea utilization by marine Synechococcus (Sakamoto \& Bryant 2001) and by freshwater Anabaenca cyclindricus (Mackerass \& Smith 1986).

Many species from all major phytoplankton taxa of freshwater and marine phytoplanktonic algae (Antia et al. 1991) and cyanobacteria (Berns et al. 1966) can use urea effectively as a source of $\mathrm{N}$ for growth. Some of these species have a somewhat notorious reputation as 'nuisance algae' and may cause toxic blooms. Potential uptake of urea by the brown tide chrysophyte, Aureococcus anophagefferens, was substantially greater than uptake of other $\mathrm{N}$ substrates including $\mathrm{NH}_{4}{ }^{+}$, a mixture of amino acids, or $\mathrm{NO}_{3}$ (Berg et al. 1997). This ability to exploit urea may have contributed to the recent prevalence of Aureococcus blooms in NE USA coastal waters (Duzurica et al. 1989, Berg et al. 1997, LaRoche et al. 1997) although this may not always be the case (Gobler \& Sañudo-Wilhelmy 2001).

Other toxic dinoflagellates that can utilize urea include Gymnodinium breve (Steidinger et al. 1998; now renamed Karenia brevis) and Pfiesteria piscicida (Lewitus et al. 1999). High levels of urea $(>1.5 \mu \mathrm{M} \mathrm{N})$ were found concomitantly with dinoflagellate blooms in commercial hybrid striped bass aquaculture ponds (Glibert \& Terlizzi 1999), suggesting that urea specifically stimulated growth of G. galatheanum, G. nelsonii, Prorocentrum minimum and Katodinium. The high abundance of dinoflagellates may also have enhanced urea excretion by the fish in these ponds. A potentially toxic cyanobacterium, Aphanizomenon ovalisporum, isolated in non-axenic cultures from Lake Kinneret, grew optimally on urea as the sole N source. Mass balance determinations indicated that this organism utilized mostly DON as a direct or indirect source of $\mathrm{N}$ rather than $\mathrm{N}_{2}$ fixation when it developed into a bloom in the lake in 1994 (Berman 1997, 2001).

We suggest that urea may be a more important source of $\mathrm{N}$ nutrition for aquatic microbiota in both freshwater and marine environments than has been generally appreciated. Further investigation of the role played by urea as a source of $\mathrm{N}$ nutrition in natural waters is certainly warranted.

\section{DFAA, DCAA, and proteins}

The importance of DFAA as sources of $\mathrm{C}, \mathrm{N}$ and energy for both marine and freshwater heterotrophic bacteria has long been known (Williams et al. 1976, Zehr et al. 1985, Wheeler \& Kirchman 1986). Release and uptake of amino acids tend to be closely linked (Fuhrman 1987) so that ambient concentrations of DFAA are usually very low and represent only a small fraction of measured DON. Nevertheless, DFAA probably account for a substantial fraction of the $\mathrm{N}$ flux into and out of the DON pool. Although bacteria are still assumed to be the major clients for utilizing DFAA in aquatic environments, it is now apparent that many phytoplankton species can also use amino acids as $\mathrm{N}$ sources (Table 3 ), most probably by virtue of possessing cell surface aminooxidases (Palenik \& Morel 1990a,b, 1991, Pantoja \& Lee 1994, Mulholland et al. 1998). These enzymes hydrolyze amino acids externally to $\mathrm{NH}_{4}{ }^{+}$, which is then taken up by the cell.

The pool of DCAA compounds (containing proteins, oligopeptides, polypeptides, and humic-bound amino acids; Hubberten et al. 1995) often comprises the largest identifiable portion of DON pools. Three main components of the DCAA fraction have been proposed (Keil \& Kirchman 1993): (1) a rapidly cycling (hours to days) protein, similar to that freshly extracted from phytoplankton; (2) a more recalcitrant, abiotically glucosylated protein that is very resistant to degradation; and (3) a pool of non-proteinaceous compounds, perhaps consisting of amino acids bound or adsorbed to humic substances or to small particles (Hubberten et al. 1994).

In the ocean, dissolved protein concentrations are low in surface waters, and increase below the euphotic zone (Bronk 2002). In some reports of dissolved protein determinations in German and Japanese lakes (Steinberg 1977, Hama \& Handa 1980, 1983), between 55 and $74 \%$ of the proteins and polypeptides were $<5 \mathrm{kDa}$. By contrast, most of the dissolved protein in the ocean appears to have a much higher MW. Some, as yet unquantified, portion of this pool consists of a ubiquitous, dissolved protein (MW 48kDa) that may be derived from porin-P, part of the phosphorus transport system in gram-negative bacterial cell walls (Tanoue 1995, Tanoue et al. 1995, 1996).

DFAA, DCAA, and protein assays

The most commonly used method for quantifying DFAA is based on pre-column derivatization with ortho-phthaldialdehyde (OPA), followed by separation with HPLC (Lindroth \& Mopper 1979, Mopper \& Lindroth 1982). A flow injection method to determine the concentrations of primary amines in seawater gave results comparable to HPLC separation (Delmas et al. 1990, Petty et al. 1992). An alternate derivatization technique using 6-aminoquinolyl-N-hydroxysuccinimidyl carbamate that detected both primary and secondary amines was insensitive to amino acid concentrations below $200 \mathrm{nM}$ (Jørgensen \& Jensen 1997). These authors noted, however, that derivatization 
procedures, such as with OPA, which tag only the primary amines, underestimate levels of DFAA and DCAA in natural waters.

Several approaches have been used to hydrolyze DCAA to DFAA. The original acid hydrolysis with $6 \mathrm{~N}$ $\mathrm{HCl}$ required $20 \mathrm{~h}$ at $110^{\circ} \mathrm{C}$ (Parsons et al. 1984). A vapor phase hydrolysis method (Tsugita et al. 1987) was modified by Keil \& Kirchman (1991a,b), who found that the modified technique gave up to 3 -fold higher DCAA concentrations than the method of Parsons et al. (1984). The vapor phase technique, combined with microwave radiation, was used by Jørgensen \& Jensen (1997) to achieve simultaneous hydrolysis of 20 samples in $20 \mathrm{~min}$. In all cases, after hydrolysis of the DCAA, the total dissolved amino acids (i.e. DCAA plus

Table 3. Freshwater and marine phytoplankton utilizing amino acids as nitrogen sources in axenic cultures. M: marine; FW: freshwater

\begin{tabular}{|c|c|c|}
\hline Organism & System & Source \\
\hline \multicolumn{3}{|l|}{ Chrysophyta } \\
\hline Cyclotella cryptica & $\mathrm{M}$ & Liu \& Hellebust (1974) \\
\hline Phaeodactylium tricornutum & M & Flynn \& Syrett (1986) \\
\hline Navicula incerte & M & Landymore \& Antia (1977) \\
\hline N. pavillardi & M & Lewin \& Hellebust (1975) \\
\hline Nitzschia angularis & M & Lewin \& Hellebust (1976) \\
\hline N. ovalis & M & Lewin \& Hellebust (1978) \\
\hline Skeletonema costatum ${ }^{a}$ & M & Fisher \& Cowdell (1982) \\
\hline Asterionella japonica $^{\mathrm{a}}$ & M & Fisher \& Cowdell (1982) \\
\hline Nitzschia closterium $^{\mathrm{a}}$ & M & Fisher \& Cowdell (1982) \\
\hline Coscinodiscus sp. ${ }^{\mathrm{a}}$ & M & Fisher \& Cowdell (1982) \\
\hline Fragilaria sp. $^{\mathrm{a}}$ & M & Fisher \& Cowdell (1982) \\
\hline Chaetoceros debile & M & Poulet \& Martin-Jezequel (1983) \\
\hline Melosira mediocris & FW & Ming \& Stephens (1985) \\
\hline \multicolumn{3}{|l|}{ Haptophyta } \\
\hline Isochrysis galbana & M & Landymore \& Antia (1977) \\
\hline Prymnesium parvum & M & Palenik et al. (1988) \\
\hline Emiliana huxleyi & M & Palenik \& Henson (1997) \\
\hline \multicolumn{3}{|l|}{ Chlorophyta } \\
\hline Platymonas subcordiformis & M & North \& Stephens (1969) \\
\hline Chlorella vulgaris & FW & Pettersen \& Knutsen (1974) \\
\hline C. fusca & FW & Richards \& Thurston (1980) \\
\hline Chlamydomonas reinhardtii & FW & Kirk \& Kirk (1978a) \\
\hline Volvox carteri & FW & Kirk \& Kirk (1978b) \\
\hline Pandorina morum & FW & Kirk \& Kirk (1978c) \\
\hline Scenedesmus obliquus & FW & Kirk \& Kirk (1978c) \\
\hline Ankisrodesmus braunnii & FW & Kirk \& Kirk (1978c) \\
\hline Tetraselmis subcordiformis & M & Qafaiti \& Stephens (1988) \\
\hline Pediastrum duplex & FW & Berman et al. (1991) \\
\hline Scenedesmus sp. & FW & Berman et al. (1991) \\
\hline \multicolumn{3}{|l|}{ Cyanobacteria } \\
\hline Anabaena variabilis & FW & Theil (1988) \\
\hline Anacystis nidulans & FW & Lee-Kaden \& Simonis (1982) \\
\hline Agmenellum quadruplicatum & M & Kapp et al. (1975) \\
\hline \multicolumn{3}{|l|}{ Pyrrophyta } \\
\hline Gymnodinium breve & M & Baden \& Mende (1979) \\
\hline Alexandrium fundyense & $\mathrm{M}$ & John \& Flynn (1999) \\
\hline
\end{tabular}

DFAA) in the sample were quantified by pre-column derivatization and separation by HPLC. The DCAA concentration was then obtained by subtracting DFAA, measured in the same, non-hydrolyzed water sample, from the concentration of DCAA plus DFAA.

Few studies have attempted to quantify or characterize dissolved proteins in natural waters. In order to isolate and identify a range of dissolved proteins in seawater from the Indian and Antarctic Oceans, Tanoue and colleagues (Tanoue 1995, Tanoue et al. 1995, 1996) used tangential-flow ultrafiltration, concentration and purification by precipitation with trichloroacetic acid and final separation with sodium dodecylsulphate-polyacrylamide gel electrophoresis (SDSPAGE). Immunochemical methods were applied to further characterize these dissolved proteins (Suzuki et al. 1997). Note that these methods are qualitative and do not provide concentrations of proteins in situ. The availability of new fluorescent tags such as Nano-orange (Molecular Probes) may lead to more sensitive and reliable methods for dissolved protein measurements.

Sources of DFAA, DCAA, and proteins

DFAA and DCAA are released from living phytoplankton directly (Myklestad et al. 1989, Bronk \& Glibert 1993a,b, Bronk et al. 1994), as well as by viral lysis or autolysis of senescent algae (Gardner et al. 1987, Sundh 1992, Agusti et al. 1998). Zooplankton generate these compounds through sloppy feeding, excretion and upon dissolution of their fecal material. Protists grazing on bacteria may also produce significant amounts of DCAA (Ferrier-Pagés et al. 1998, Rosenstock \& Simon 2001). Release of DFAA and DCAA may occur from the solubilization of organic seston, of marine or lake snow particles, or transparent proteinaceous particles (Long \& Azam 1996, Grossart \& Simon 1998, Berman \& Viner-Mozzini 2001).

The most detailed study of seasonal and vertical dynamics and turnover of DFAA and DCAA in freshwaters was made by Simon and colleagues (Simon 1998, Simon \& Rosenstock 1992, Rosenstock \& Simon 1993, 2001, Simon et al. 1998) in Lake Constance, Germany. Maximum DFAA release was in winter until the onset of the spring phytoplankton bloom. 
DCAA and protein peaked during the spring and summer algal blooms. Protein accounted for 1 to $31 \%$ of DCAA (Rosenstock \& Simon 2001). These authors also give a detailed analysis of the seasonal changes of the LMW and HMW fractions of the DCAA pool in this lake. The microplankton fraction (1 to $140 \mu \mathrm{m})$, especially phytoplankton and ciliates, was always the major source of DFAA and protein. A somewhat similar pattern was observed in 2 Swedish lakes where DFAA were preferentially released in spring, in contrast to more protein appearing during summer (Sundh 1992).

\section{Sinks for DFAA, DCAA, and proteins}

Much is known about the turnover of DFAA and their significance for growth of heterotrophic bacteria in both freshwater and marine environments (Gardner \& Lee 1975, Williams et al. 1976, Jørgensen 1982, 1987, Gardner et al. 1987, 1998, Keil \& Kirchman 1991a,b, Simon \& Rosenstock 1992, Jørgensen et al. 1993, Middelboe et al. 1995). Recently Ouverney \& Fuhrman (2000) reported the significant finding that marine Archaea are also capable of taking up amino acids at nanomolar levels.

Extensive dependence of marine heterotrophic bacteria on DFAA and DCAA has been documented in estuarine and coastal waters in Long Island Sound (Fuhrman 1987), Delaware Estuary (Coffin 1989, Middelboe et al. 1995), Chesapeake Bay (Fuhrman 1990), the Mississippi River plume (Cotner \& Gardner 1993), as well as in pelagic waters (subarctic Pacific; (Kirchman et al. 1989a,b, Keil \& Kirchman 1991a,b). DFAA were used preferentially to DCAA unless the concentration of the former was very low (Keil \& Kirchman 1991a,b). This may have been the situation in the extremely oligotrophic surface waters of the Northern Sargasso Sea, where protein was the dominant form of ON utilized for bacterial production (25 to $60 \%$; Keil \& Kirchman 1999). In locations where DFAA concentrations were high with rapid turnover, or when DFAA turnover exceeded bacterial $\mathrm{N}$ demand, high rates of $\mathrm{NH}_{4}{ }^{+}$regeneration were often observed (Kirchman et al. 1989a,b, Keil \& Kirchman 1991a,b, Cotner \& Gardner 1993, Gardner et al. 1993).

In some environments, DCAA were of equal or even greater importance than DFAA for bacterioplankton growth (Coffin 1989, Coffin et al. 1993, Kroer et al. 1994, Rosenstock \& Simon 2001). In Lake Constance, DCAA and DFAA supported 45 and $13 \%$ of bacterial biomass production, respectively (Rosenstock \& Simon 2001), as an annual average. The sum of DFAA and protein supported $58 \%$ of bacterial C and $80 \%$ of bacterial N demands (Rosenstock \& Simon 2001). There is 1 report of bacterial utilization of DCAA, mostly bound to humic substances, in a Pennsylvania stream (Volk et al. 1997).

As shown in Table 3, many marine and freshwater algae can grow on amino acids as $\mathrm{N}$ sources (reviewed in Flynn \& Butler 1986); additional earlier data are also given in Antia et al. (1975), Turner (1979), and Neilson \& Larsson (1980). Care must be taken in extrapolating results from culture experiments to the real environment if unrealistically high concentrations of organic substrates were used. For example, although the toxic dinoflagellate Alexandrium fundyense could assimilate a wide range of amino acids, with uptake being greatest during the exponential phase (Ogata et al. 1996), this organism was incapable of using amino acids for growth (John \& Flynn 1999). Nevertheless, the discovery of cell surface amino-oxidases in many phytoplankton species (Palenik \& Morel 1990a,b, Pantoja \& Lee 1994) suggests that amino acids can indeed serve as $\mathrm{N}$ sources for algae in aquatic systems (Mulholland et al. 1998).

There is a dearth of information on the fate of dissolved protein in natural waters. Some proteins are undoubtedly degraded enzymatically to peptides and DFAA (Hollibaugh \& Azam 1983, Pantoja \& Lee 1999a,b), and some are transformed to recalcitrant organic forms (Keil \& Kirchman 1994). Curiously, there is 1 report of heterotrophic flagellates using dissolved proteins (ferritin, casein, albumin, and concavalin A) as a direct source of nutrition (Tranvik et al. 1993). We have no idea how widespread or important this process might be, but this observation raises the interesting possibility that members of the planktonic community, other than bacteria and phytoplankton, can use proteins and other constituents of the DON pool.

\section{Nucleic acids and their breakdown products}

Nucleic acids, and degradation products such as nucleotides, purines and pyrimidines, are relatively neglected constituents of DON pools. Dissolved DNA and RNA (dDNA and dRNA) are part of the general pool of HMW DON, and would be expected to result from cell lysis, sloppy zooplankton feeding, and protistan grazing (Weinbauer \& Peduzzi 1995a,b, Ishii et al. 1998, Kawabata et al. 1998). In a 2-stage chemostat experiment, Turk et al. (1992) showed that nanoflagellates grazing on bacteria released dDNA. Pioneering studies of dDNA and particulate DNA dynamics in marine and freshwater environments were published by Paul et al. $(1988,1989)$ and others (Beebee 1991, De Flaun et al. 1987, Karl \& Bailiff 1989).

Reported concentrations of dDNA in marine and freshwaters range from several to $\sim 100 \mu \mathrm{g} \mathrm{N}{ }^{-1}$ (Paul et al. 1987, Bailiff \& Karl 1991, Ishii et al. 1998). How- 
ever, in a recent study, Siuda \& Chrost (2000) pointed out some difficulties in quantifying the concentrations of dDNA. A considerable, but not easily defined, part of total dDNA may be adsorbed on particles or colloids and substantial proportions of measured dDNA may actually derive from viral DNA that has passed through 0.45 or $0.2 \mu \mathrm{m}$ filters (Beebee 1991, Weinbauer \& Peduzzi 1995b).

D-DNA assays

Four analytical methods have been used to quantify ambient concentrations of dDNA in natural waters: (1) Staining with Hoechst dye (De Flaun et al. 1986). (2) Precipitation with CTAB (cetyltrimethyl-ammonium bromide) followed by fluorometric detection after staining with DAPl (4,6 diamidino 2 phenylindole; Karl \& Bailiff 1989, Siuda \& Güde 1996a). (3) Measuring the decrease in DAPl fluorescence upon enzymatic hydrolysis of dDNA by DNase (Siuda \& Chrost 2000). This method is believed to obviate overestimates (from 27 to $54 \%$ ) of actual DNA concentrations as given by the CTAB technique and to give a more appropriate measure of 'available' dDNA. (4) Detection with ethidium bromide (Sakano \& Kamatani 1992).

\section{D-DNA sinks}

Paul et al. (1989) were the first to measure in situ dDNA turnover using ${ }^{3} \mathrm{H}-\mathrm{DNA}$ in oligotrophic and eutrophic subtropical Florida lakes. The turnover rates were rapid $(\sim 10 \mathrm{~h})$ in both systems. Similarly rapid turnover times for dDNA were reported in Lake Constance (Siuda \& Güde 1996a). Slower rates were found for the hydrolysis of plasmid DNA added to river and marine waters (Alvarez et al. 1996) or to epilimnetic waters in Lake Biwa, Japan (Matsui et al. 2001). In the latter case, the dDNA rapidly lost its transformation ability and was completely hydrolyzed after $170 \mathrm{~h}$. This observation was consistent with earlier results (Paul et al. 1988) showing that DNA gene sequences from added DNA were not assimilated by estuarine bacteria. By contrast, in the hypolimnion of Lake Biwa, exogenous dDNA was not perceptibly degraded, and seeded plasmid DNA did not lose its transformation efficiency even after $170 \mathrm{~h}$ (Matsui et al. 2001). This result raises the possibility that dDNA may be stable in hypolimnetic lakes or deep marine waters for a relatively long time (weeks or more), and thus may remain capable of causing genetic transformation. It is therefore feasible that recombinant DNA from genetically modified microorganisms, released intentionally or unintentionally, might retain its transformation potency for extended periods in hypolimnetic or deep aquatic environments.

In studies with seawater bacterial cultures, Jørgensen et al. (1993) found that dDNA could supply up to 5 and $10 \%$ of the bacterial $\mathrm{C}$ and $\mathrm{N}$ requirement, respectively, in batch cultures of marine bacteria. However, most studies have focused on dDNA (C:N:P ratio, 10:4:1) in marine and freshwaters as a potential source of phosphorus rather than N nutrition (Siuda \& Güde 1996b). Degradation of dDNA was rapid in a P-limited region of the Adriatic Sea, but much slower in an N-limited region of the Californian Bight (Turk et al. 1992).

The incorporation of dDNA by natural bacteria in estuarine microsms was also studied by Jørgensen \& Jacobsen (1996). When no nutrients were added, dDNA supplied 6,8 and $46 \%$ of bacterial $C, N$ and $P$ requirements, respectively. Tests of uptake preference by the bacterioplankton for DNA of different sizes $(100,250$ and $569 \mathrm{bp})$ showed that the smallest fragments were the most readily utilized.

With 2 exceptions (Koenings \& Hooper 1973, Sakano \& Kamatani 1992), there do not appear to be any studies of dRNA in natural waters.

\section{Nucleotides and derivatives}

The dissolved nucleotide that has received the most research attention has been ATP (Azam \& Hodson 1977). Bjørkman \& Karl (2001), using a new method to measure dissolved ATP and GTP (guanosine tri-phosphate), reported concentrations of $70 \mathrm{ng} \mathrm{l}^{-3}$ in summer and $\sim 30 \mathrm{ng} \mathrm{l}^{-3}$ in winter of dissolved ATP in the 0 to 100 m layer of the oligotrophic North Pacific Ocean (Stn Aloha). Although active cycling of nucleotides and their purine bases probably occurs, this process may be more important in providing $\mathrm{P}$ rather than $\mathrm{N}$ to the microplankton.

Purines and pyrimidines and their derivatives are also potentially significant DON compounds. Purines, such as guanine and hypoxanthine, are rapidly degraded to yield urea and/or $\mathrm{NH}_{4}^{+}$that can be easily used by phytoplankton and bacteria (Antia et al. 1980, 1991, Berman et al. 1999). Pyrimidines are also degraded but seem to be less effectively taken up by microbiota than purines (Antia et al. 1991). No data concerning the rates of cycling of these compounds in aquatic systems are available, but this pathway of $\mathrm{N}$ flux may be important in some environments (Antia et al. 1980).

Hypoxanthine, guanine, uric acid and their derivatives (e.g. allantoic acid) can support microalgal growth N requirements for many algal taxa (Droop 1961, Guillard \& Ryther 1962, Guillard 1963, Antia \& Chorney 
1968, Kapp et al. 1975, Oliveira \& Huynh 1990, Lisa et al. 1995, Berman \& Chava 1999). One source for these purines may be excretion from ciliates (Antia et al. 1980). Cytoplasmic inclusions composed mainly of hypoxanthine and guanine were isolated from the marine hymenostone ciliate Parauronema acutum (Soldo et al. 1978). Guanine, hypoxanthine, adenine and dihydrouracil were excreted from freshwater ciliates, such as species of Paramecium (Soldo \& Van Wagtendonk 1961). Berman et al. (1987) observed the release of ATP in 'reconstituted' seawater cultures containing bacteria, pico-phytoplankton and heterotrophic flagellates. We are not aware of any more recent studies that have investigated the release of purines or related ON compounds from protists in aquatic environments.

\section{Amino sugars}

There have been few studies of dissolved amino sugars in aquatic environments. Amino sugars may be produced as breakdown products of bacterial, cyanobacterial and algal cell walls, chitin, and microbial and fish mucus (Blackwell et al. 1967, Sutherland 1985, Nakagawa et al. 1988, Bertocchi et al. 1990, Decho 1990). Amino sugars have been found in lakes (Göcke 1970, Steinberg 1977, Bunte \& Simon 1999), reservoirs (Hejzlar 1989), and rivers (Ittekkot et al. 1982, Chudoba et al. 1986). In contrast to freshwater, amino sugars in marine systems cannot be detected by ionexchange HPLC and the pulsed amperometric method used for dissolved monosaccharides (Mopper et al. 1992) because they are selectively removed in the desalting step prior to HPLC (M. Simon pers. comm.). However, McCarthy et al. (1998) determined amino sugars in marine HMW DON using thermal desorbtion-mass spectrometry and pyrolysis.

The reported concentrations of amino sugars (predominantly glucosamine and $\mathrm{N}$-acetyl-glucosamine) range from about 10 to $100 \mu \mathrm{g} \mathrm{l}^{-1}$, somewhat lower but in the same order of magnitude as levels of amino acids. Nedoma et al. (1994), using a modification of the method of Barnes (1984), reported concentrations of dissolved amino sugars ranging from 20 to $1200 \mu \mathrm{g} \mathrm{l}^{-1}$ in 2 mountain lakes, 2 reservoirs, 2 river backwaters and 2 highly eutrophic fishponds. Approximately $42 \%$ of the dissolved amino sugars in the Rimov Reservoir, Czech Republic, consisted of N-acetyl-glucosamine and glucosamine (Hejzlar 1989). Other amino sugars identified were 2-amino-2-deoxygalacturonic acid and fucosamine, probably originating from bacterial cell walls. Using autoradiography, Nedoma et al. (1994) showed that microorganisms (bacteria, cyanobacteria and diatoms), capable of taking up $\mathrm{N}$-acetylglucosamine, were present in all the water bodies studied. Overall, the in- ference from this work is that glucosamine and N-acetylglucosamine could be important bacterial substrates for organic $\mathrm{C}$ and $\mathrm{N}$ in some aquatic environments. Early studies by Antia \& Chorney (1968) and Berland et al. (1976) showed that many species of marine algae could use glucosamine for $\mathrm{N}$ nutrition. Several non-axenic freshwater algal cultures also grew successfully on this compound as a sole N source (Berman \& Chava 1999).

\section{Humic substances}

Variable, but often substantial, proportions of DON are comprised of poorly characterized humic substances falling into 2 operationally defined categories: humic acids, insoluble at $\mathrm{pH}<2.0$ and obtained by retention on XAD-8 resin, and fulvic acids, separated with XAD-4 resin (Aiken 1985, 1988). Schnitzer (1985) identified 2 types of nitrogenous humic components: (1) a major fraction consisting of LMW N compounds (such as amino acids, purines, pyrimidines) loosely held by, or adsorbed to, the humic core structure, and (2) an $\mathrm{N}$ fraction that is integral to the humic molecule itself (Lytle \& Perdue 1981). Presumably only the first humic component is actively involved in short-term $\mathrm{N}$ flux. Most humic compounds in freshwater and coastal environments are of terrestrial origin, but some of them in pelagic oceans and large lakes may be derived from organic matter produced autochthonously.

Not much is known about the potential of humic substances to serve as a source of $\mathrm{N}$ for planktonic microbiota, although it now appears that they may be somewhat less refractory than previously believed (Amon \& Benner 1994, Moran \& Hodson 1994a,b, Gardner et al. 1996). Humic bound DCAA has been shown to be at least partially available to bacteria (Hubberten et al. 1994, 1995, Volk et al. 1997, Amon et al. 2001). Some attention has been focused on the potential impact of these compounds on phytoplankton development in coastal waters. Increasing amounts or different types of humic compounds derived from human activities may have caused eutrophication and the proliferation of toxic dinoflagellates in these waters. The $\mathrm{N}$ bound to humic substances may be directly available to some algal groups, such as dinoflagellates (Granéli et al. 1985, Carlsson \& Granéli 1993, Carlsson et al. 1993). When humic material, isolated from a river, was added to a phytoplankton assemblage from a Swedish fjord, both bacterial and algal production were stimulated (Carlsson et al. 1993). In this instance, the bacteria used both $\mathrm{C}$ and $\mathrm{N}$ from the humic compounds directly for growth; subsequently, the phytoplankton exploited the regenerated DON and $\mathrm{NH}_{4}{ }^{+}$. As yet, these studies have been limited to estuarine and coastal waters in the Baltic Sea and the Atlantic coast of the USA. 


\section{UTILIZATION OF MULTIPLE N SOURCES}

A somewhat neglected topic is the simultaneous uptake and utilization of mixtures of $\mathrm{N}$ substrates (organic or inorganic/organic) by phytoplankton (Antia et al. 1991). With some exceptions (Pintner \& Provasoli 1963, Pettersen 1975, Flynn \& Wright 1986, Collos 1987), few studies have examined how algae or bacteria respond to multiple ON sources, although this situation corresponds more closely to real life environments than experiments with uptake of only a single ON source. The inhibitory effects of $\mathrm{NH}_{4}{ }^{+}$on urea and DFAA uptake have been extensively documented but, as yet, little is known about the interplay of various DON sources that are used by phytoplankton in environments with limited DIN availability. Ricketts (1988) studied the separate and combined uptake and assimilation of $\mathrm{NH}_{4}{ }^{+}, \mathrm{NO}_{3}{ }^{-}$, urea, and glycine in the marine prasinophyte, Tetraselemis strata, and concluded that this organism maintained a relatively constant rate of total N-assimilation, irrespective of the mixture of utilizable N-sources. In eutrophic Lake Okeechobee, Florida, Gu et al. (1997) analyzed total $\mathrm{N}$ utilization by a summer cyanobacterial bloom and found that $53 \%$ of the uptake was from $\mathrm{NH}_{4}{ }^{+}, 19 \%$ was from $\mathrm{NO}_{3}{ }^{-}, 16 \%$ was from urea, and $12 \%$ was by $\mathrm{N}_{2}$ fixation. The growth of a bloom of Aphanizomenon ovalisporum in Lake Kinneret used DON and DIN in a ratio of $\sim 4: 1$ for $\mathrm{N}$ supply, with only a minor amount of the $\mathrm{N}$ requirement derived from $\mathrm{N}_{2}$ fixation (Berman 1997, 2001). A similar situation was reported in Glebokie Lake, Poland, where cyanobacterial growth was mainly supported by DON with only a small proportion contributed by $\mathrm{N}_{2}$ fixation (Krupka 1989). Presumably the higher energetic costs involved in fixing $\mathrm{N}_{2}$ compared to using reduced $\mathrm{N}$ in organic compounds will dispose azotrophic cyanobacteria to exploit suitable DON sources preferentially if these are available.

There have been several studies of the use of multiple $\mathrm{N}$ sources by marine bacteria (Middelboe et al. 1995, Jørgensen et al. 1999). Tupas \& Koike (1990) examined the differential uptake of $\mathrm{NH}_{4}{ }^{+}$and DON (mostly DCAA) by natural bacterial assemblages in seawater cultures that were enriched with dissolved substances released by the mussel Mytilis edulis. Even when large amounts of DON were utilized, $\mathrm{NH}_{4}{ }^{+}$continued to be taken up and incorporated into the bacterial cells. Simultaneous assimilation and regeneration of $\mathrm{NH}_{4}{ }^{+}$occurred, contradicting the idea that $\mathrm{NH}_{4}{ }^{+}$utilization occurs in natural bacterial populations only when ON is limiting. Middelboe et al. (1995) found that bacterial populations in batch cultures from the Delaware Bay Estuary derived very different proportions of their $\mathrm{N}$ requirements from DFAA, DCAA and $\mathrm{NH}_{4}{ }^{+}$depending on whether they were C- or $\mathrm{N}$ - limited, or in the exponential growth phase. In Santa Rosa Sound, DFAA were the dominant $\mathrm{N}$ source for bacteria, followed by DCAA and then $\mathrm{NH}_{4}{ }^{+}$(Jørgensen et al. 1999).

In Lake Constance, Simon \& Rosenstock (1992) and Rosenstock \& Simon (1993) followed the simultaneous bacterial uptake of $\mathrm{NH}_{4}{ }^{+}$, DFAA and DCAA and found distinct seasonal patterns. As noted by Simon \& Rosenstock (1992), when studying the bacterial use of multiple $\mathrm{N}$ substrates it is important to consider the availability of $\mathrm{NH}_{4}{ }^{+}$and carbohydrates versus amino acids and, in addition, the molar percent of available DFAA and DCAA relative to the amino acid requirements for protein synthesis. DFAA and DCAA are taken up without any $\mathrm{NH}_{4}{ }^{+}$regeneration if the molar percent composition of the amino acid pool is similar to the amino acid requirements for protein synthesis. When 1 or a few amino acids are assimilated in excess, they are deaminated to release $\mathrm{NH}_{4}{ }^{+}$. Simon (1991) and Simon \& Rosenstock (1992) used the mole percent composition of the bacterial intracellular amino acid pools and the intracellular isotope dilution of individual DFAAs to estimate the relative importance of $\mathrm{NH}_{4}{ }^{+}$and DFAA in bacterial $\mathrm{N}$ uptake.

A particularly interesting and ecologically significant case of uptake of multiple $\mathrm{N}$ sources is that of Trichodesmium (reviewed in Mulholland \& Capone 2000). This azotrophic marine cyanobacterium is quantitatively the most important fixer of $\mathrm{N}_{2}$ in the pelagic ocean. Cells of Trichodesmium are usually found as spherical aggregates (puffs) or fusiform bundles (tufts), each containing several hundred multicellular filaments (trichomes). Not all cells within filaments or colonies contain nitrogenase, the enzyme required for fixing $\mathrm{N}_{2}$. Most of the active $\mathrm{N}_{2}$ fixation occurs during the few hours around midday and only in some parts of the trichome (Berman-Frank et al. 2001). Recently it has become evident that in the ocean, trichomes and colonies of Trichodesmium simultaneously fix $\mathrm{N}_{2}$ and take up combined $\mathrm{N}$, including forms of DON $\left(\mathrm{NH}_{4}{ }^{+}\right.$, $\mathrm{NO}_{3}{ }^{-}$, urea, and amino acids; Mulholland \& Capone 2000). In cultures, Trichodesmium cells grown on urea were reported to be devoid of nitrogenase (Ohki et al. 1992), but this was not the case under all growth conditions (Mulholland et al. 1999).

Trichodesmium colonies that are actively fixing $\mathrm{N}_{2}$ also release DON and $\mathrm{NH}_{4}{ }^{+}$(Capone et al. 1994, Glibert \& Bronk 1994, Mulholland et al. 1999). It has been suggested that $\mathrm{N}$, primarily in the form of amino acids, is released by actively growing cells and that the released DON is utilized by those Trichodesmium cells that lack nitrogenase, possibly through the mediation of cell surface amino-oxidases.

The details of $\mathrm{N}$ cycling within Trichodesmium colonies in the ocean are presently the focus of 
intense research. This process is obviously complex and certainly involves other organisms usually associated with Trichodesmium colonies, such as harpacticoid copepod grazers (O'Neil et al. 1996, O'Neil 1998). Some, perhaps considerable, part of the DON uptake attributed to Trichodesmium may be due to associated heterotrophic bacteria. Nevertheless, it seems clear that in their natural environment, Trichodesmium are simultaneously using a variety of $\mathrm{N}$ sources, including DON.

In general, situations where multiple sources of $\mathrm{N}$ are utilized concomitantly may well be the rule rather than the exception and may reflect the micro-heterogeneity (patchiness) of aquatic systems. Undoubtedly the use of multiple nutrient sources by aquatic microorganisms is a topic deserving more extensive research attention.

\section{CONCLUSION}

As we have documented, there has been considerable progress in our understanding of various aspects of aquatic DON over the last decade. Nevertheless, there are still few studies that have quantified the amounts of $\mathrm{N}$ flux into, and out of, the DON pool relative to the other major $\mathrm{N}$ pools in any specific lake, estuary or marine system. Although it seems clear that components of DON pools such as urea or amino acids may sometimes be 'major players' in $\mathrm{N}$ flux, we still lack a general evaluation of the quantitative or qualitative importance of DON cycling in freshwater and marine ecosystems.

In this review we have attempted to summarize the current 'state of the science' in respect to aquatic DON. Our take-home message is simple. The DON fraction in natural waters is by no means inert. DON should not be neglected either as a source or as a sink for N. Many biotic and abiotic processes generate DON in both marine and freshwater systems. The DON pool acts as a source of $\mathrm{N}$ nutrition for many microorganisms, and in so doing may affect the species composition of the ambient microbial assemblage. There is still a need for a greater appreciation and understanding of the potential role of DON as a dynamic participant in aquatic ecosystems, especially in freshwater environments.

Acknowledgments. We are grateful to Ms. R. Hershkowitz and Ms. A. Jensen for secretarial help. We also thank a quartet of reviewers for constructive comments and criticism. This work was supported by National Science Foundation grant OCE-0095940 to D.A.B. This paper is a contribution of Israel Oceanographic and Limnological Research and is VIMS Contribution 2535 from the Virginia Institute of Marine Science, College of William and Mary.

\section{LITERATURE CITED}

Abell J, Emerson S, Renaud P (2000) Distributions of TOP, TON, and TOC in the North Pacific subtropical gyre: implications for nutrient supply in the surface ocean and remineralization in the upper thermocline. J Mar Res 58:203-222

Agusti S, Satta MP, Mura MP, Benavent E (1998) Dissolved esterase activity as a tracer of phytoplankton lysis: evidence of high phytoplankton lysis rates in the northeastern Mediterranean. Limnol Oceanogr 43:1836-1849

Aiken GR (1985) Isolation and concentration techniques for aquatic humic substances. In: Aiken GR, McKnight DM, Wershaw RL, McCarthy P (eds) Humic substances in soil, sediment and water: geochemistry, isolation and characterization. John Wiley \& Sons, New York, p 363-385

Aiken GR (1988) A critical evaluation of the use of macro-porous resins for the isolation of aquatic humic substances. In: Frimmel FH, Christman RF (eds) Humic substances and their role in the environment. John Wiley \& Sons, New York, p 15-28

Alberts JJ, Takács M (1999) Importance of humic substances for carbon and nitrogen transport into southeastern United States estuaries. Org Geochem 30:385-395

Alldredge AL, Passow U, Logan BE (1993) The abundance and significance of a class of large, transparent organic particles in the ocean. Deep-Sea Res 40:1131-1140

Alvarez AJ, Yumet GM, Santiago CL, Toranzos GA (1996) Stability of manipulated plasmic DNA in aquatic environments. Environ Toxicol Water Qual 11:129-135

Amon RMW, Benner R (1994) Rapid cycling of high-molecular-weight dissolved organic matter in the ocean. Nature 369:549-551

Amon RMW, Fitznar HP, Benner R (2001) Linkages among the bioreactivity, chemical composition and diagenic state of marine dissolved organic matter. Limnol Oceanogr 46: $287-297$

Antia NJ, Chorney V (1968) Nature of the nitrogen compounds supporting phototrophic growth of the marine cryptomonad Hemiselemis virescens. J Protozool 15:198-201

Antia NJ, Berland BR, Bonin DJ, Maestrini SY (1975) Comparative evaluation of certain organic and inorganic sources of nitrogen for phototrophic growth of marine microalgae. J Exp Mar Biol Assoc UK 55:519-539

Antia NJ, Berland BR, Bonin DJ (1980) Proposal for an abridged nitrogen turnover cycle in certain marine planktonic systems involving hypoxanthine-guanine excretions by ciliates and their reutilization by phytoplankton. Mar Ecol Prog Ser 2:97-103

Antia NJ, Harrison PJ, Oliveira L (1991) Phycological reviews: the role of dissolved organic nitrogen in phytoplankton nutrition, cell biology, and ecology. Phycologia 30:1-89

Armstrong FAJ, Tibbitts S (1968) Photochemical combustion of organic matter in seawater for nitrogen, phosphorus, and carbon determination. J Mar Biol Assoc UK 48:143-152

Armstrong FAJ, Williams PM, Strickland JDH (1966) Photooxidation of organic matter in sea water by ultra-violet radiation, analytical and other applications. Nature 211: $481-483$

Azam F, Hodson RE (1977) Size distribution and activity of marine microheterotrophs. Limnol Oceanogr 22:492-501

Baden DG, Mende TJ (1979) Amino acid utilization by Gymnodinium breve. Phytochemistry 18:247-251

Bailiff MD, Karl DM (1991) Dissolved and particulate DNA dynamics during a spring bloom in the Antarctic Peninsula region 1986-1987. Deep-Sea Res 38:1077-1095

Barnes CFJ (1984) A modified method for the rapid analysis of nanomolar levels of amino sugar in tissues and body fluids. Lab Pract 33:78-81 
Bates NR, Hansell DA (1999) A high resolution study of surface layer hydrographic and biogeochemical properties between Chesapeake Bay and Bermuda. Mar Chem 64:1-16

Beebee T (1991) Analysis, purification and quantification of extracellular DNA from aquatic environments. Freshw Biol 25:525-532

Benner R, Biddanda B, Black B, McCarthy M (1997) Abundance, size distribution, and stable carbon and nitrogen isotopic compositions of marine organic matter isolated by tangential-flow ultrafiltration. Mar Chem 57:243-263

Berg GM, Glibert PM, Lomas MW, Burford MA (1997) Organic nitrogen uptake and growth by the chrysophyte Aureococcus anophagefferens during a brown tide event. Mar Biol 129:377-387

Berg GM, Glibert PM, Jørgensen NOG, Balode M, Purina I (2001) Variability in inorganic and organic nitrogen uptake associated with riverine nutrient input in the Gulf of Riga, Baltic Sea. Estuaries 24:204-214

Berg GM, Repeta DJ, Laroche J (2002) Dissolved organic nitrogen hydrolysis rates in axenic cultures of Aureococcus anophagefferens (Pelagophyceae): comparison with heterotrophic bacteria. Appl Environ Microbiol 68:401-404

Berland BR, Bonin DJ, Maestrini SY, Lizaraga-Partida ML, Antia NJ (1976) The nitrogen concentration requirement of glucosamine for supporting effective growth of marine microalgae. J Mar Biol Assoc UK 56:629-637

Berman T (1974) Urea in the waters of Lake Kinneret (Sea of Galilee). Limnol Oceanogr 19:977-980

Berman T (1997) Dissolved organic nitrogen utilization by an Alphanizomenon bloom in Lake Kinneret. J Plankton Res 19:577-586

Berman T (2001) The role of DON and the effect of N:P ratios on occurrence of cyanobacterial blooms: implications from the outgrowth of Aphanizomenon in Lake Kinneret. Limnol Oceanogr 46:443-447

Berman T, Chava S (1999) Algal growth on organic compounds as nitrogen sources. J Plankton Res 21:1391-1421

Berman T, Viner-Mozzini Y (2001) Abundance and characteristics of polysaccharide and proteinaceous particles in Lake Kinneret. Aquatic Microb Ecol 25:255-264

Berman T, Nawrocki M, Taylor GT, Karl DM (1987) Nutrient flux between bacteria, bacterivorous nanoplanktonic protists and algae. Mar Microb Food Webs 2:69-81

Berman T, Chava S, Kaplan B, Wynne D (1991) Dissolved organic substrates as phosphorus and nitrogen sources for axenic batch cultures of freshwater green algae. Phycologia 30:339-345

Berman T, Bechemin C, Maestrini SY (1999) Release of ammonium and urea from dissolved organic nitrogen in aquatic exosystems. Aquat Microb Ecol 16:295-302

Berman-Frank I, Lundgren P, Chen Y, Kupper H, Kolber Z, Bergmann B, Falkowski PG (2001) Segregation of nitrogen fixation and oxygenic photosynthesis in the marine cyanobacterium Trichodesmium. Science 294:1534-1539

Berns DS, Holohan S, Scott E (1966) Urease activity in bluegreen algae. Science 152:1077-1078

Bertilsson S, Stepanauskas R, Cuadros-Hansson R, Granéli W, Wikner J, Tranvik L (1999) Photochemically induced changes in bioavailable carbon and nitrogen pools in a boreal watershed. Aquat Microb Ecol 19:47-56

Bertocchi C, Navarini L, Cesaro A (1990) Polysaccharides from cyanobacteria. Carbohydr Polym 12:127-153

Bjorkman KM, Karl DM (2001) A novel method for the measurement of dissolved adenosine and guanosine triphosphate in aquatic habitiats: applications to marine microbial ecology. J Microbiol Methods 47:159-167

Blackwell J, Parker KD, Rudall KM (1967) Chitin fibers of the diatom Thalassiosira fluviatilis and Cyclotella cryptica. J Mol Biol 28:383-385

Bratbak G, Jacobsen A, Heldal M (1998) Viral lysis of Phaeocystis pouchetii and bacterial secondary production. Aquat Microb Ecol 16:11-16

Bronk DA (2002) Dynamics of organic nitrogen. In: Hansell DA, Carlson CA (eds) Biogeochemistry of marine dissolved organic matter. Academic Press, San Diego, p 153-247

Bronk DA, Glibert PM (1993a) Application of a ${ }^{15} \mathrm{~N}$ tracer method to the study of dissolved organic nitrogen uptake during spring and summer in Chesapeake Bay. Mar Biol 115:501-508

Bronk DA, Glibert PM (1993b) Contrasting patterns of dissolved organic nitrogen release by two size fractions of estuarine plankton during a period of rapid $\mathrm{NH}_{4}{ }^{+}$consumption and $\mathrm{NO}_{2}{ }^{-}$production. Mar Ecol Prog Ser 96:291-299

Bronk DA, Ward BB (1999) Gross and net nitrogen uptake and DON release in the euphotic zone of Monterey Bay, California. Limnol Oceanogr 44:573-585

Bronk DA, Ward BB (2000) Magnitude of DON release relative to gross nitrogen uptake in marine systems. Limnol Oceanogr 45:1879-1883

Bronk DA, Glibert PM, Ward BB (1994) Nitrogen uptake, dissolved organic nitrogen release, and new production. Science 265:1843-1846

Bronk DA, Glibert PM, Malone TC, Banahan S, Sahlsten E (1998) Inorganic and organic nitrogen cycling in Chesapeake Bay: autotrophic versus heterotrophic processes and relationships to carbon flux. Aquat Microb Ecol 15:177-189

Bronk DA, Lomas M, Glibert PM, Schukert KJ, Sanderson MP (2000) Total dissolved nitrogen analysis: comparisons between the persulfate, UV and high temperature oxidation method. Mar Chem 69:163-178

Bunte C, Simon M (1999) Bacterial turnover of dissolved free monosaccharides in a mesotrophic lake. Limnol Oceanogr 44:1862-1870

Burdige DJ, Zheng S (1998) The biogeochemical cycling of dissolved organic nitrogen in estuarine sediments. Limnol Oceanogr 43:1796-1813

Bury SJ, Owens NJP, Preston T (1995) ${ }^{13} \mathrm{C}$ and ${ }^{15} \mathrm{~N}$ uptake by phytoplankton in the marginal ice zone of the Bellingshausen Sea. Deep-Sea Res II 42:1225-1252

Bushaw KL, Zepp RG, Tarr MA, Schulz-Jander D and 5 others (1996) Photochemical release of biologically labile nitrogen from dissolved organic matter. Nature 381:404-407

Bushaw-Newton KL, Moran MA (1999) Photochemical formation of biologically available nitrogen from dissolved humic substances in coastal marine systems. Aquat Microb Ecol 18:285-292

Capone D, Ferrier M, Carpenter E (1994) Amino acid cycling in colonies of the planktonic marine cyanobacterium Trichodesmium thiebautii. Appl Environ Microbiol 60: 3989-3995

Capone DG (2000) The marine nitrogen cycle. In: Kirchman DL (ed) Microbial ecology of the oceans. John Wiley \& Sons, New York, p 455-494

Carlson CA, Hansell DA, Peltzer ET, Smith WO Jr (2000) Stocks and dynamics of dissolved and particulate organic matter in the Southern Ross Sea, Antarctica. Deep-Sea Res II 42:3201-3225

Carlsson P, Granéli E (1993) Availability of humic bound nitrogen for coastal phytoplankton. Estuar Coast Shelf Sci 36:433-447

Carlsson P, Segatto AZ, Granéli E (1993) Nitrogen bound to humic matter of terrestrial origin - a nitrogen pool for coastal phytoplankton? Mar Ecol Prog Ser 97:105-116

Chen JC, Cheng SY (1993) Urea excretion by Penaeus japon- 
icus Bate exposed to different concentrations of ambient ammonia. J Exp Mar Biol Ecol 173:1-9

Cherrier J, Bauer JE, Druffel ERM (1996) Utilization and turnover of labile dissolved organic matter by bacterial heterotrophs in eastern North Pacific surface waters. Mar Ecol Prog Ser 139:267-279

Cho BC, Park M, Shim J, Azam F (1996) Significance of bacteria in urea dynamics in coastal surface waters. Mar Ecol Prog Ser 142:19-26

Cho BC, Azam F (1995) Urea decomposition by bacteria in the Southern California Bight and its implications for the mesopelagic nitrogen cycle. Mar Ecol Prog Ser 122:21-26

Chudoba J, Hejzlar J, Dolezal M (1986) Microbial polymers in the aquatic environment. 3. Isolation from river, potable and underground water and analysis. Water Res 20: 1223-1227

Cochlan WP, Price NM, Harrison PJ (1991) Effects of irradiance on nitrogen uptake by phytoplankton: comparison of frontal and stratified communities. Mar Ecol Prog Ser 69: 103-116

Coffin RB (1989) Bacterial uptake of dissolved free and combined amino acids in estuarine waters. Limnol Oceanogr 34:531-542

Coffin RB, Connolly JP, Harris PS (1993) Availability of dissolved organic carbon to bacterioplankton examined by oxygen utilization. Mar Ecol Prog Ser 101:9-22

Collier JL, Brahamsla B, Palenik B (1999) The marine cyanobacerium, Synechococcus sp. WH7805, requires urease to utilize urea as a nitrogen source: molecular genetic and biochemical analysis of the enzyme. Microbiol 145:447-454

Collos Y (1987) Calculations of ${ }^{15} \mathrm{~N}$ uptake rates by phytoplankton assimilating one or several nitrogen sources. Appl Radiat Isot 38:275-282

Conover RJ, Gustavson KR (1999) Sources of urea in arctic seas: zooplankton metabolism. Mar Ecol Prog Ser 179: 41-54

Cornell S, Rendell A, Jickells T (1995) Atmospheric inputs of dissolved organic nitrogen to the oceans. Nature 376 : 243-246

Cornell SE, Jickells T, Thornton CA (1998) Urea in rainwater and atmospheric aerosol. Atmos Environ 32:1903-1910

Cornell SE, Mace K, Coeppicus S, Duce R, Huebert R, Jickells $\mathrm{T}$, Zhuang LZ (2001) Organic nitrogen in Hawaiian rain and aerosol. J Geophys Res 106:7973-7983

Cotner J, Smith WO Jr, Gardner WS (1993) Heterotrophic bacterial mediation of ammonium and dissolved free amino acid fluxes in the Mississippi River plume. Mar Ecol Prog Ser 93:75-87

Crowder A, Painter DS (1991) Submerged macrophytes in Lake Ontario: current knowledge, importance, threats to stability, and need studies. Can J Fish Aquat Sci 48: 1539-1545

Dagg MJ (1974) Loss of prey body contents during feeding by an aquatic predator. Ecology 55:9903-9906

Daly KL, Wallace DWR, Smith WO Jr, Skoog A, Lara R, Gosselin M, Falck E, Yager PL (1999) Non-Redfield carbon and nitrogen cycling in the Arctic: effects of ecosystem structure and dynamics. J Geophys Res 104:3185-3199

Decho AW (1990) Microbial exoploymer secretions in ocean environments: their role(s) in food webs and marine processes. Oceanogr Mar Biol Annu Rev 28:73-153

De Flaun MF, Paul JH, Davis D (1986) Simplified method for dissolved DNA determination in aquatic environments. Appl Environ Microbiol 52:654-659

De Flaun MF, Paul JH, Jeffrey WH (1987) Distribution and molecular weight of dissolved DNA in a subtropical estuarine and oceanic environments. Mar Ecol Prog Ser 38:65-73

Delmas D, Frickla MG, Linley EAS (1990) Dissolved primary amine measurement by flow injection analysis with ophthaldialdeyde: comparison with high performance liquid chromatography. Mar Chem 29:145-154

Diaz F, Raimbault P (2000) Nitrogen regeneration and dissolved organic nitrogen release during spring in a NW Mediterranean coastal zone (Gulf of Lions): implications for the estimation of new production. Mar Ecol Prog Ser 197:51-65

Dittmar T, Fitznar HP, Kattner G (2001) Origin and biogeochemical cycling of organic nitrogen in the East Arctic Ocean as evident from D- and L-amino acids. Geochim Cosmochim Acta 65:4103-4114

Droop MR (1961) Haematococcus pluvialis and its allies. III. Organic nutrition. Revue Algol 4:247-259

Duzurica S, Lee C, Cosper EM (1989) Role of environmental variables, specifically organic compounds and micronutrients, in the growth of the chrysophyte Aureococcus anaphagefferens. In: Cosper EM, Bricelj VM, Carpenter EJ (eds) Novel phytoplankton blooms. Springer-Verlag, Berlin, p 229-252

Ferrier-Pagés C, Karner M, Rassoulzadegan F (1998) Release of dissolved amino acids by flagellates and ciliates grazing on bacteria. Oceanol Acta 21:485-494

Fisher NS, Cowdell RA (1982) Growth of marine planktonic diatoms on inorganic and organic nitrogen. Mar Biol 72: $147-155$

Flynn KJ, Berry LS (1999) The loss of organic nitrogen during marine primary production may be significantly overestimated when using ${ }^{15} \mathrm{~N}$ substrates. Proc R Soc Lond B 266: $641-647$

Flynn KJ, Butler I (1986) Nitrogen sources for the growth of microalgae: role of dissolved free amino acids. Mar Ecol Prog Ser 34:281-304

Flynn KJ, Syrett PJ (1986) Utilization of L-lysine and Larginine by the diatom Phaeodactylum tricornutum. Mar Biol 90: 159-163

Flynn KJ, Wright CRN (1986) The simultaneous assimilation of ammonium and L-arginine by the marine diatom Phaeodactylum tricornutum Bohlin. J Exp Mar Biol Ecol 95: $257-269$

Fuhrman J (1987) Close coupling between release and uptake of dissolved free amino acids in seawater studied by an isotope dilution approach. Mar Ecol Prog Ser 37:45-52

Fuhrman J (1990) Dissolved free amino acid cycling in an estuarine outflow plume. Mar Ecol Prog Ser 66:197-203

Fuhrman JA (1999) Marine viruses and their biogeochemical and ecological effects. Nature 399:541-548

Gao H, Zepp RG (1998) Factors influencing photoreactions of dissolved organic matter in a coastal river of the southeastern United States. Environ Sci Technol 32:2940-2946

Gardner WS, Lee GF (1975) The role of amino acids in the nitrogen cycle of Lake Mendota. Limnol Oceanogr 20: $379-388$

Gardner WS, Chandler JF, Laird GA, Carrick HJ (1987) Source and fate of dissolved free amino acids in eplimnetic Lake Michigan water. Limnol Oceanogr 32:1353-1362

Gardner WS, Cotner JB, Herche LR (1993) Chromatographic measurement of nitrogen mineralization rates in marine coastal waters with ${ }^{15} \mathrm{~N}$. Mar Ecol Prog Ser 93:65-73

Gardner WS, Benner R, Amon R, Cotner J, Caveletto J, Johnson J (1996) Effects of high molecular weight dissolved organic matter on the nitrogen dynamics on the Mississippi River plume. Mar Ecol Prog Ser 133:287-297

Gardner WS, Cavaletto JF, Bootsma HA, Lavrentyev PJ, Tan- 
vone F (1998) Nitrogen cycling rates and light effects in tropical Lake Maracaibo, Venezuela. Limnol Oceanogr 43: $1814-1825$

Glibert PM, Bronk DA (1994) Release of dissolved organic nitrogen by marine diazotrophic cyanobacteria Trichodesmium spp. Appl Environ Microbiol 36:3996-4000

Glibert PM, Terlizzi DE (1999) Cooccurrence of elevated urea levels and dinoflagellate blooms in temperate estuarine aquaculture ponds. Appl Environ Microbiol 65:5594-5596

Glibert PM, Garside C, Fuhrman JA, Roman MR (1991) Timedependent coupling of inorganic and organic nitrogen uptake and regeneration in the plume of the Chesapeake Bay estuary and its regulation by large heterotrophs. Limnol Oceanogr 36:895-909

Glibert PM, Conley DJ, Fisher TR, Harding LW Jr, Malone TC (1995) Dynamics of the 1990 winter/spring bloom in Chesapeake Bay. Mar Ecol Prog Ser 122:27-43

Gobler CJ, Sañudo-Wilhelmy SA (2001) Effects of organic carbon, organic nitrogen, inorganic nutrients, and iron additions on the growth of phytoplankton and bacteria during a brown tide bloom. Mar Ecol Prog Ser 209:19-34

Gobler CJ, Hutchins DA, Fisher NS, Cosper EM, SañudoWilhelmy SA (1997) Release and bioavailability of C, N, P, $\mathrm{Se}$, and Fe following viral lysis of a marine chrysophyte. Limnol Oceanogr 42:1492-1504

Gobler CJ, Renaghan MJ, Buck NJ (2002) Impacts of nutrients and grazing mortality on the abundance of Aureococcus anophagefferens during a New York brown tide bloom. Limnol Oceanogr 47:129-141

Göcke K (1970) Untersuchungen über Abgabe und Aufnahme von Aminosäuren und Polypeptiden durch Planktonorganismen. Arch Hydrobiol 67:285-367

Goeyens L, Kindermans N, Yusuf MA, Elskens M (1998) A room temperature procedure for the manual determination of urea in seawater. Estuar Coast Shelf Sci 47:415-418

Gordeev VV, Martin JM, Sidorov IS, Sidorova MV (1996) A reassessment of the Eurasian River input of water sediment, major elements, and nutrients to the Arctic Ocean. Am J Sci 296:664-691

Granéli E, Edler L, Gedziorowska D, Nyman U (1985) Influence of humic and fulvic acids on Prorocentrum minimum. In: Anderson DM, White AW, Baden EG (eds) Third Int Conf Toxic Dinoflagellates. Elsevier Science Publishers, New York

Grossart HP, Simon M (1998) Significance of limnetic organic aggregates (lake snow) for the sinking flux of particulate organic matter in a large lake. Aquat Microb Ecol 15: 115-125

Gu B, Havens K, Schelske C, Rosen B (1997) Uptake of dissolved nitrogen by phytoplankton in a eutrophic subtropical lake. J Plankton Res 19:759-770

Guillard RRL (1963) Organic sources of nitrogen for marine diatoms. In: Oppenheimer $\mathrm{CH}$ (ed) Symp Marine Microbiology. Thomas, Springfield, IL, p 93-104

Guillard RRL, Ryther JJ (1962) Studies of marine planktonic diatoms. Can J Microbiol 8:229-239

Haga H, Nagata T, Sakamoto M (2001) Ammonium regeneration within the euphotic zone. In: Saijo Y, Hayashi H (eds) Lake Kizaki: limnology and ecology of a Japanese lake. Backhuys, Leiden, p 207-215

Hama T, Handa N (1980) Molecular weight distribution and characterization of dissolved organic matter from lake waters. Arch Hydrobiol 90:106-120

Hama T, Handa N (1983) The seasonal variation of organic constituents in a eutrophic lake, Lake Suwa, Japan. Part II. Dissolved organic matter. Arch Hydrobiol 98:443-462

Hansell DA (1993) Results and observations from the mea- surement of DOC and DON in seawater using a hightemperature catalytic oxidation technique. Mar Chem 41: 195-202

Hansell DA, Carlson CA (2001) Biogeochemistry of total organic carbon and nitrogen in the Sargasso Sea: control by convective overturn. Deep-Sea Res II 48:1649-1667

Hansell DA, Feely RA (2000) Atmospheric inter-tropical convergence impacts surface ocean carbon and nitrogen biogeochemistry in the western tropical Pacific. Geophys Res Lett 27:1013-1016

Hansell PA, Goering JJ (1989) A method for estimating uptake and production rates for urea in seawater using ${ }^{14} \mathrm{C}$ urea and ${ }^{15} \mathrm{~N}$ urea. Can J Fish Aquat Sci 46:198-202

Hansell D, Waterhouse T (1997) Controls on the distributions of organic carbon and nitrogen in the eastern Pacific Ocean. Deep-Sea Res 44:843-857

Hansell DA, Williams PM, Ward BB (1993) Measurements of DOC and DON in the Southern California Bight using oxidation by high temperature combustion. Deep-Sea Res 40: 219-234

Hansen JW, Udy JW, Perry CJ, Dennison WC, Lomstein BA (2000) Effect of the seagrass Zostera capricorni on sediment microbial processes. Mar Ecol Prog Ser 199:83-96

Harrison WG, Head EJH, Conover RJ, Longhurst AR, Sameoto DD (1985) The distribution and metabolism of urea in the eastern Canadian Arctic. Deep-Sea Res 32: $23-42$

Harrison WG, Harris LR, Karl DM, Knauer GA, Redalje DG (1992) Nitrogen dynamics at the VERTEX time-series site. Deep-Sea Res 39:1535-1552

Hasagawa T, Koike I, Mukai H (2000a) Dissolved organic nitrogen dynamics in coastal waters and the effect of copepods. J Exp Mar Biol Ecol 244:219-238

Hasagawa T, Koike I, Mukai H (2000b) Estimation of dissolved organic nitrogen release by micrograzers in natural plankton assemblages. Plankton Biol Ecol 47:23-30

Hasagawa T, Koike I, Mukai H (2001) Fate of food nitrogen in marine copepods. Mar Ecol Prog Ser 210:167-174

Hejzlar J (1989) Dissolved amino sugars in the Rimov Reservoir (Czechoslovakia). Ergeb Limnol 33:291-301

Hollibaugh JT, Azam F (1983) Microbial degradation of dissolved proteins in seawater. Limnol Oceanogr 28: $1104-1116$

Hopkinson CS Jr, Cifuentes L, Burdige D, Fitzwater S and 6 others (1993) DON subgroup report. Mar Chem 41:23-36

Hopkinson CS Jr, Fry B, Nolin AL (1997) Stoichiometry of dissolved organic matter dynamics on the continental shelf of the northeastern USA. Cont Shelf Res 17:155-166

Hopkinson CS Jr, Buffam I, Hobbie J, Vallino J and 11 others (1998) Terrestrial inputs of organic matter to coastal ecosystems: an intercomparison of chemical characteristics and bioavailablility. Biogeochemistry 43:211-234

Hoppe HG, Ducklow HW, Karrasch B (1993) Evidence for dependency of bacterial growth on enzymatic hydrolysis of particulate organic matter in the mesopelagic ocean. Mar Ecol Prog Ser 93:277-283

Horrigan SG, McCarthy JJ (1981) Urea uptake by phytoplankton at various stages of nutrient depletion. J Plankton Res 3:403-413

Hubberten U, Lara RJ, Kattner G (1994) Amino acid composition of seawater and dissolved humic substances in the Greenland Sea. Mar Chem 45:121-128

Hubberten U, Lara RJ, Kattner G (1995) Refractory organic compounds in polar waters: relationship between humic substances and amino acids in the Arctic and Antarctic. J Mar Res 53:137-149

Ishii N, Kawabata Z, Nakano S, Min MG, Takata R (1998) 
Microbial interactions responsible for dissolved DNA production in a hypereutrophic pond. Hydrobiologia 380: $67-76$

Ittekkot V, Spitzy A, Lammertz U (1982) Data on dissolved carbohydrates and amino acids in world rivers: a documentation. Mitt Geol Palaeontol Inst Univ Hamburg 52: $575-584$

Jackson GA, Williams PW (1985) Importance of dissolved organic nitrogen and phosphorus to biological nutrient cycling. Deep-Sea Res 32:223-235

Jansson M (1979) Nutrient budgets and the regulation of nutrient concentrations in a small sub-arctic lake in northern Sweden. Freshw Biol 9:213-231

Johannes RE (1965) Influence of marine protozoa on nutrient regeneration. Limnol Oceanogr 10:433-442

John EH, Flynn KJ (1999) Amino acid uptake by the toxic dinoflagellate Alexandrium fundyense. Mar Biol 133: $11-19$

Jørgensen NOG (1982) Heterotrophic assimilation and occurrence of dissolved free amino acids in a shallow water estuary. Mar Ecol Prog Ser 8:145-159

Jørgensen NOG (1987) Free amino acids in lakes: concentrations and assimilation rates in relation to phytoplankton and bacterial production. Limnol Oceanogr 32:97-111

Jørgensen NOG, Jacobsen CS (1996) Bacterial uptake and utilization of dissolved DNA. Aquat Microb Ecol 11: 263-270

Jørgensen NOG, Jensen RE (1997) Determination of dissolved combined amino acids using microwater-assisted hydrolysis and HPLC pre-column derivatization for labeling of primary and secondary amines. Mar Chem 57: 287-297

Jørgensen NOG, Kroer N, Coffin RB, Yang XH, Lee C (1993) Dissolved free amino acids, combined amino acids, and DNA as sources of carbon and nitrogen to marine bacteria. Mar Ecol Prog Ser 98:135-148

Jørgensen NOG, Kroer N, Coffin RB (1994) Utilization of dissolved nitrogen by heterotrophic bacterioplankton: effect of substrate $\mathrm{C} / \mathrm{N}$ ratio. Appl Environ Microbiol 60: 4124-4133

Jørgensen NOG, Tranvik L, Edling H, Granéli W, Lindell M (1998) Effects of sunlight on occurrence and bacterial turnover of specific carbon and nitrogen compounds in lake water. FEMS Microbiol Ecol 25:217-227

Jørgensen NOG, Kroer N, Coffin RB, Hoch MP (1999) Relations between bacterial nitrogen metabolism and growth efficiency in an estuarine and an open-water ecosystem. Aquat Microb Ecol 18:247-261

Jumars PA, Penry DL, Baross JA, Perry MJ, Frost BW (1989) Closing the microbial loop: dissolved carbon pathway to heterotrophic bacteria from incomplete ingestion, digestion, and absorption in animals. Deep-Sea Res 36:483-495

Kähler P, Koeve W (2001) Marine dissolved organic matter: can its C:N ratio explain carbon overconsumption. DeepSea Res II 48:49-62

Kähler P, Bjørnsen PK, Lochte K, Antia A (1997) Dissolved organic matter and its utilization by bacteria during spring in the Southern Ocean. Deep-Sea Res II 44:341-353

Kapp R, Stevens SE, Fox JL (1975) A survey of available nitrogen sources for the growth of blue-green alga, Agmenellum quadruplicatum. Arch Microbiol 104:135-138

Karl DM (1993) Microbial processes in the Southern Ocean. In: Friedmann EI (ed) Antarctic microbiology. Wiley-Liss, New York, p 1-63

Karl DM, Bailiff MD (1989) The measurement and distribution of dissolved nucleic acids in aquatic environments. Limnol Oceanogr 34:543-558
Karl DM, Christian JR, Dore JE, Letelier RM (1996) Microbiological oceanography in the region west of the Antarctic peninsula: microbial dynamics, nitrogen cycle, and carbon flux. Antarct Res Ser 70:303-332

Kawabata Z, Ishii N, Nasu M, Min MG (1998) Dissolved DNA produced through a prey-predator relationship in a species-defined aquatic microcosm. Hydrobiologia 385:71-76

Keil RG, Kirchman DL (1991a) Dissolved combined amino acids in marine waters as determined by a vapor-phase hydrolysis method. Mar Chem 33:243-259

Keil RG, Kirchman DL (1991b) Contribution of dissolved free amino acids and ammonium to the nitrogen requirements of heterotrophic bacterioplankton. Mar Ecol Prog Ser 73: $1-10$

Keil RG, Kirchman DL (1993) Dissolved combined amino acids: chemical form and utilization by marine bacteria. Limnol Oceanogr 38:1256-1270

Keil RG, Kirchman DL (1994) Abiotic transformations of labile protein to refractory protein in sea water. Mar Chem 45: 187-196

Keil RG, Kirchman DL (1999) Utilization of dissolved protein and amino acids in the northern Sargasso Sea. Aquat Microb Ecol 18:293-800

Kerner M, Spitzy A (2001) Nitrate regeneration coupled to degradation of different size fractions of DON by the picoplankton in the Elbe Estuary. Microb Ecol 41:69-81

Kieber RJ, Li A, Seaton PJ (1999) Production of nitrite from the photodegradation of dissolved organic matter in natural waters. Environ Sci Technol 33:993-998

Kirchman D, Soto Y, Van Wanbeck F, Bianchi M (1989a) Bacterial production in the Rhone River plume: effect of mixing on relationships among microbial assemblages. Mar Ecol Prog Ser 53:267-275

Kirchman DL, Keil RG, Wheeler PA (1989b) The effect of amino acids on ammonium utilization and regeneration by heterotrophic bacteria in the subarctic Pacific. Deep-Sea Res 36:1763-1776

Kirk DL, Kirk MM (1978a) Carrier-mediated uptake of arginine and urea by Chlamydomonas reinhardtii. Plant Physiol 61:556-560

Kirk DL, Kirk MM (1978b) Carrier-mediated uptake of arginine and urea by Volvox carteri f. nagariensis. Plant Physiol 61:549-555

Kirk DL, Kirk MM (1978c) Amino acids and urea uptake in ten species of chlorophyta. J Phycol 14:198-203

Koenings JP, Hooper FF (1973) Organic phosphorus compounds of a northern Michigan bog, bog-lake system. Mich Acad 5:295-310

Kokkinakis SA, Wheeler PA (1988) Uptake of ammonium and urea in the northeast Pacific: comparison between netplankton and nanoplankton. Mar Ecol Prog Ser 43: 113-124

Koopmans DJ, Bronk DA (2002) Photochemical production of inorganic nitrogen from dissolved organic nitrogen in waters of two estuaries and adjacent surficial groundwaters. Aquat Microb Ecol 26:295-304

Koroleff F (1983) Determination of nutrients. In: Grasshoff K, Ehrhardt M, Kremling K (eds) Methods of seawater analysis. Verlag Chemie, New York, p 125-187

Kroer N, Jørgensen NOG, Coffin RB (1994) Utilization of dissolved nitrogen by heterotrophic bacterioplankton: a comparison of three ecosystems. Appl Environ Microbiol 60: 4116-4123

Krupka HM (1989) Transformations of nitrogen forms in epilimnion of the eutrophic Glebockie Lake (Masurian Lake District, Poland). Pol Arch Hydrobiol 36:26-96

Lampert W (1978) Release of dissolved organic carbon by 
grazing zooplankton. Limnol Oceanogr 23:831-834

Landymore AF, Antia NJ (1977) Growth of a marine diatom and a haptophycean alga on phenylalanine or tyrosine as sole nitrogen source. Phycology 13:231-238

LaRoche J, Nuzzi R, Waters R, Wyman K, Falkowski PG, Wallace DWR (1997) Brown Tide blooms in Long Island's coastal waters linked to interannual variability in groundwater flow. Global Change Biol 3:397-410

Lee-Kaden J, Simonis W (1982) Amino acid uptake and energy coupling dependent on photosynthesis in Anacystis nidulans. J Bacteriol 151:229-236

Lewin J, Hellebust JA (1975) Heterotrophic nutrition of the marine pennate diatom Navicula pavillardi Hustedt. Can J Microbiol 21:1335-1342

Lewin J, Hellebust JA (1976) Heterotrophic nutrition of the marine pennate diatom Nitzschia angularis var. affinis. Mar Biol 36:313-320

Lewin J, Hellebust JA (1978) Utilization of glutamate and glucose for heterotrophic growth by the marine pennate diatom Nitzschia laevis. Mar Biol 47:1-7

Lewitus AJ, Willis BM, Hayes KC, Burkholder JM, Glasgow HB, Glibert PM, Burke MK (1999) Mixotrophy and nitrogen uptake by Pfiesteria piscicida (Dinophyceae). J Phycol 35:1430-1437

Lewitus AJ, Koepfler ET, Pigg RJ (2000) Use of dissolved organic nitrogen by a salt marsh phytoplankton bloom community. Arch Hydrobiol Spec Issues Adv Limnol 55: 441-456

Libby P, Wheeler P (1997) Particulate and dissolved organic nitrogen in the central and eastern equatorial Pacific. Deep-Sea Res 44:345-361

Lindroth P, Mopper K (1979) High performance liquid chromatographic determination of subpicomole amounts of amino acids by precolumn fluorescence derivatization with ophthaldialdehyde. Anal Chem 51:1667-1674

Lisa T, Piedras P, Cardenas J, Pineda M (1995) Utilization of adenine and guanine as nitrogen sources by Chlamydomonas reinhardtii cells. Plant Cell Env 18:583-588

Liu MS, Hellebust JA (1974) Uptake of amino acids by the marine centric diatom Cyclotella cryptica. Can J Microbiol 20:1109-1118

Loh AN, Bauer JE (2000) Distribution, partitioning and fluxes of dissolved and particulate organic C, N and P in the eastern North Pacific and Southern Oceans. Deep-Sea Res I 47:2287-2316

Lomas MW, Glibert PM, Berg GM, Burford M (1996) Characterization of nitrogen uptake by natural populations of Aureococcus anaphagefferens (Chrysophyceae) as a function of incubation duration, substrate concentration, light, and temperature. J Phycol 32:907-916

Lomas MW, Trice TM, Glibert PM, Bronk DA, McCarthy JJ (2002) Temporal and spatial dynamics of urea concentrations in Chesapeake Bay: biological versus physical forcing. Estuaries 25:469-482

Lomstein AA, Blackburn TH, Henriksen K (1989) Aspects of nitrogen and carbon cycling in the northern Bering Shelf sediment: the significance of urea turnover in the mineralization of $\mathrm{NH}_{4}$. Mar Ecol Prog Ser 57:237-247

Lomstein BA, Jensen AGU, Hansen JW, Andreasen JB, Hansen LS, Berntsen J, Kunzendorf H (1998) Budgets of sediment nitrogen and carbon cycling in the shallow water of Knebel Vig, Denmark. Aquat Microb Ecol 14:69-80

Long R, Azam F (1996) Abundant protein-containing particles in the sea. Aquat Microb Ecol 10:213-221

López-Veneroni D, Cifuentes LA (1994) Transport of dissolved organic nitrogen in Mississippi River plume and Texas-Louisiana continental shelf near-shore waters.
Estuaries 17:796-808

Lytle CR, Perdue EM (1981) Free, proteinaceous, and humicbound amino acids in river water containing high concentrations of aquatic humics. Environ Sci Technol 15: $224-228$

Mackerass AH, Smith GD (1986) Urease activity of the cyanobacterium Anabaena cylindrica. J Gen Microbiol Rev 132:2749-2752

Maguer JF, Lecorre P, Madec C (1996) Seasonal variations in nitrogen uptake in shallow well-mixed waters (Western English Channel). Oceanol Acta 19:529-537

Manny BA, Johnson WC, Wetzel RG (1994) Nutrient additions by waterfowl to lakes and reservoirs: predicting their effects on productivity and water quality. Hydrobiologia 280:121-132

Matsui K, Honjo M, Kawabata Z (2001) Estimation of the fate of dissolved DNA in thermally stratified lake water from the stability of exogenous plasmid DNA. Aquat Microb Ecol 26:95-102

Matthews E (1994) Nitrogenous fertilizers: global distribution of consumption and associated emissions of nitrous oxide and ammonia. Global Biogeochem Cycles 8:411-439

McCarthy JJ (1970) A urease method for urea in seawater. Limnol Oceanogr 15:309-313

McCarthy JJ (1972) The uptake of urea by natural populations of marine phytoplankton. Limnol Oceanogr 17: $738-748$

McCarthy JJ, Kamykowski D (1972) Urea and other nitrogenous nutrients in La Jolla Bay during February, March, and April, 1970. Fish Bull 70:1261-1274

McCarthy JJ, Taylor WR, Taft JL (1977) Nitrogenous nutrition of the plankton in the Chesapeake Bay. I. Nutrient availability and phytoplankton preferences. Limnol Oceanogr 22:996-1011

McCarthy JJ, Wynne D, Berman T (1982) The uptake of nitrogenous nutrients by Lake Kinneret microplankton. Limnol Oceanogr 24:673-680

McCarthy M, Hedges J, Benner R (1996) Major biochemical composition of dissolved high molecular weight organic matter in seawater. Mar Chem 55:281-297

McCarthy M, Pratum T, Hedges J, Benner R (1997) Chemical composition of dissolved organic nitrogen in the ocean. Nature 390:150-154

McCarthy MD, Hedges JI, Benner R (1998) Major bacterial contribution to marine dissolved organic nitrogen. Science 281:231-234

Menzel DW, Vaccaro RF (1964) The measurement of dissolved organic and particulate carbon in seawater. Limnol Oceanogr 9:138-142

Metzler P, Glibert P, Gaeta S, Ludlam J (1997) New and regenerated production in the South Atlantic off Brazil. Deep-Sea Res 44:363-384

Middelboe M, Borch NH, Kirchman DL (1995) Bacterial utilization of dissolved free amino acids, dissolved combined amino acids and ammonium in the Delaware Bay estuary: effects of carbon and nitrogen limitation. Mar Ecol Prog Ser 128:109-120

Middelboe M, Kroer N, Jørgensen NOG, Pakulski D (1998) Influence of sediment on pelagic carbon and nitrogen turnover in a shallow Danish Estuary. Aquat Microb Ecol 14:81-90

Middelburg JJ, Nieuwenhuize J (2000) Nitrogen uptake by heterotrophic bacteria and phytoplankton in the nitraterich Thames estuary. Mar Ecol Prog Ser 203:13-21

Miller CA, Glibert PM (1998) Nitrogen excretion by the calanoid copepod Acartia tonsa: results from mesocosm experiments. J Plankton Res 20:1767-1780 
Milligan AS, Harrison PJ (2000) Effects of non-steady state iron limitation on nitrogen assimilatory enzymes in the marine diatom Thalassiosira weissflogii (Bacillariophycea). J Plankton Res 36:78-86

Ming L, Stephens GC (1985) Uptake of free amino acids by the diatom Melosira mediocris. Hydrobiologia 128:187-191

Mitamura O, Matsumoto K (1981) Uptake rate of urea nitrogen and decomposition rate of urea carbon at the surface microlayer in Lake Biwa. Verh Internat Ver Limnol 21: 556-564

Mitamura O, Saijo Y (1981) Studies on the seasonal changes of dissolved organic carbon, nitrogen, phosphorus and urea concentrations in Lake Biwa. Arch Hydrobiol 91: $1-14$

Mitamura O, Saijo Y (1986) Urea metabolism and its significance in the nitrogen cycle in the euphotic layer of Lake Biwa: regeneration of urea and ammonia. Arch Hydrobiol 107:425-440

Mitamura O, Cho KS, Hong SU (1989) Urea decomposition and its turnover time in euphotic layer of reservoirs in the North Han River system. Korean J Limnol 22:227-238

Mitamura O, Cho SK, Hong SU (1994) Urea decomposition associated with the activity of microorganisms in surface waters of the North Han River. Arch Hydrobiol 131: 231-242

Mitamura O, Saijo Y, Hino K (1995) Cycling of urea associated with photosynthetic activity of phytoplankton in the euphotic zone of tropical lakes, Brazil. Jpn J Limnol 56: 95-105

Mitamura O, Kawashima M, Maeda H (2000) Urea degradation by picophytoplankton in the euphotic zone of Lake Biwa. Limnology 1:19-26

Mopper K, Lindroth P (1982) Diel and depth variations in dissolved free amino acids and ammonium in the Baltic Sea determined by shipboard HPLC analysis. Limnol Oceanogr 27:366-347

Mopper K, Schultz CA, Chevelot L, Germaine C, Revuelta R, Dawson R (1992) Determination of sugars in unconcentrated seawater and other natural waters by liquid chromatography and pulsed amperometric detection. Environ Sci Technol 26:133-138

Moran MA, Hodson RE (1994a) Dissolved humic substances of vascular plant origin in a coastal marine environment. Limnol Oceanogr 39:762-771

Moran MA, Hodson RE (1994b) Support of bacterioplankton production by dissolved humic substances from three marine environments. Mar Ecol Prog Ser 110:241-247

Moran MA, Zepp RG (1997) Role of photoreactions in the formation of biologically labile compounds from dissolved organic matter. Limnol Oceanogr 42:1307-1316

Moran MA, Zepp RG (2000) UV radiation effects on microbes and microbial processes. In: Kirchman DL (ed) Microbial ecology of the oceans. Wiley-Liss, New York, p 201-228

Morell JM, Corredor JE (2001) Photomineralization of fluorescent dissolved organic matter in the Orinoco River plume: estimation of ammonium release. J Geophys Res 106: $16807-816813$

Mortazavi B, Iverson RL, Landing WM, Lewis FG, Huang W (2000) Control of phytoplankton production and biomass in a river-dominated estuary: Apalachicola Bay, Florida, USA. Mar Ecol Prog Ser 198:19-31

Mulholland MR, Capone DG (2000) The physiology of the marine $\mathrm{N}_{2}$ fixing cyanobacteria Trichodesmium. Trends Plant Sci 5:148-153

Mulholland MR, Glibert PM, Berg GM, Van Heukelem L, Pantoja S, Lee C (1998) Extracellular amino acid oxidation by microplankton: a cross-system comparison. Aquat
Microb Ecol 15:141-152

Mulholland MR, Ohki K, Capone DG (1999) Nitrogen utilization and metabolism relative to patterns of $\mathrm{N}_{2}$ fixation in cultures of Trichodesmium NIBB1067. J Phycol 35: 977-988

Mulvenna PF, Savidge G (1992) A modified manual method for the determination of urea in seawater using diacetylmonoxime reagent. Estuar Coast Shelf Sci 34:429-438

Münster U, Albrecht D (1994) Dissolved organic matter. In: Overbeck J, Chrost RJ (eds) Microbial ecology of Lake Plussee. Springer-Verlag, New York, p 24-62

Myklestad S, Holm-Hansen O, Varum KM, Volcani BE (1989) Rate of release of extracellular amino acids and carbohydrates from the marine diatom Chaetoceros affinis. J Plankton Res 11:763-773

Nagao F, Miyazaki T (1999) A modified ${ }^{15} \mathrm{~N}$ tracer method and new calculation for estimating release of dissolved organic nitrogen by freshwater planktonic algae. Aquat Microb Ecol 16:309-314

Nagao F, Miyazaki T (2002) Release of dissolved organic nitrogen from Scenedesmus quaricauda (Chlorophyta) and Microcystis novcekii (Cyanobacteria). Aquat Microb Ecol 27:275-284

Nagata T (2000) Production mechanisms of dissolved organic matter. In: Kirchman DL (ed) Microbial ecology of the oceans. John Wiley \& Sons, New York, p 121-152

Nagata T, Kirchman DL (1996) Bacterial degradation of protein adsorbed to model submicron particles in seawater. Mar Ecol Prog Ser 132:241-248

Nakagawa H, Aasakawa M, Enomoto N (1988) Diversity in the carbohydrate moieties of mucus glycoproteins of various fishes. Bull Soc Sci Fish 54:1653-1658

Nedoma J, Vrba J, Hejzlar J, Simek K, Strasrabovam V (1994) $\mathrm{N}$-acetyl-glucosamine dynamics in freshwater environments: concentrations of amino sugars, extracellular enzyme activities and microbial uptake. Limnol Oceanogr 39:1088-1100

Neilson AH, Larsson T (1980) The utilization of organic nitrogen for growth of algae: physiological aspects. Physiol Plant 48:542-553

Newell BS, Morgan B, Cundy J (1967) The determination of urea in seawater. J Mar Res 25:201-202

North BB, Stephens GC (1967) Uptake and assimilation of amino acids by Playtomonas. Biol Bull (Woods Hole) 133: $391-400$

North BB, Stephens GC (1969) Dissolved amino acids and Platymonas. Biol Bull 133:391-400

Nydahl F (1978) On the peroxidisulfate oxidation of total nitrogen in waters to nitrate. Water Res 12:1123-1130

Ogata T, Koike K, Nomura S, Kodama M (1996) Utilization of organic substances for growth and toxin production by Alexandrium tamarense. In: Yasumoto T, Oshima $\mathrm{Y}$, Fukuyo Y (eds) Harmful and toxic algal blooms. UNESCO, Paris, p 343-346

Ogawa H, Fukuda R, Koike I (1999) Vertical distributions of dissolved organic carbon and nitrogen in the Southern Ocean. Deep-Sea Res I 46:1809-1826

Ogawa H, Amagai Y, Koike I, Keiser K, Benner R (2001) Production of refractory dissolved organic matter by bacteria. Science 292:917-920

Ohki K, Zehr JP, Fujita Y (1992) Regulation of nitrogenase activity in relation to the light-dark regime in the filamentous non-heterocystous cyanobacterium Trichodesmium sp. J Gen Microbiol 138:2679-2685

Oliveira L, Huynh H (1990) Phototrophic growth of microalgae with allantoic acid or hypoxanthine serving as nitrogen source, implications for purine-N utilization. Can 
J Fish Aquat Sci 47:351-356

O'Neil JM (1998) The colonial cyanobacterium Trichodesmium as a physical and nutritional substrate for the harpacticoid copepod Macrosetella gracilis. J Plankton Res 20:43-59

O'Neil JM, Metzler PM, Glibert PM (1996) Ingestion of ${ }^{15} \mathrm{~N}_{2}$ labelled Trichodesmium sp. and ammonium regeneration by the harpacticoid copepod Macrosetella gracilis. Mar Biol 125:89-96

Ouverney CC, Fuhrman JA (2000) Marine planktonic archaea take up amino acids. Appl Environ Microbiol 66: $4829-4833$

Paerl HW (1997) Coastal eutrophication and harmful algal blooms: importance of atmospheric deposition and groundwater as 'new' nitrogen and other nutrient sources. Limnol Oceanogr 42:1154-1165

Palenik B, Henson SE (1997) The use of amides and other organic nitrogen sources by the phytoplankton Emiliana huxleyi. Limnol Oceanogr 42:1544-1551

Palenik B, Morel FMM (1990a) Comparison of cell-surface L-amino acid oxidases from several marine phytoplankton. Mar Ecol Prog Ser 59:195-201

Palenik B, Morel FMM (1990b) Amino acid utilization by marine phytoplankton: a novel mechanism. Limnol Oceanogr 35:260-269

Palenik B, Morel FMM (1991) Amine oxidases of marine phytoplankton. Appl Environ Microbiol 57:2440-2443

Palenik B, Kieber DJ, Morel FMM (1988) Dissolved organic nitrogen use by phytoplankton: the role of cell-surface enzymes. Biol Oceanogr 6:347-354

Pantoja S, Lee C (1994) Cell-surface oxidation of amino acids in seawater. Limnol Oceanogr 39:1718-1726

Pantoja S, Lee C (1999a) Peptide decomposition by extracellular hydrolysis in coastal seawater and salt marsh sediment. Mar Chem 63:273-291

Pantoja S, Lee C (1999b) Molecular weight distribution of proteinaceous material in Long Island Sound sediments. Limnol Oceanogr 44:1323-1330

Parsons TR, Maita Y, Lalli C (1984) A manual of chemical and biological methods for seawater analysis. Pergamon Press, Oxford

Paul JH, Jeffrey WH, DeFlaun MF (1987) Dynamics of extracellular DNA in the marine environment. Appl Environ Microbiol 53:170-179

Paul JH, DeFlaun MF, Jeffrey WH, David AW (1988) Seasonal and diel variability in dissolved DNA and in microbial biomass and activity in a subtropical estuary. Appl Environ Microbiol 54:718-727

Paul JH, Jeffrey WH, David AW, DeFlaun MF, Cazares LH (1989) Turnover of extracellular DNA in eutrophic and olgotrophic freshwater environments of southwest Florida. Appl Environ Microbiol 55:1823-1828

Pedersen AGU, Thomsen TR, Lomstein BA, Jørgensen NOG (2001) Bacterial influence on amino acid enantiomerization in a coastal marine sediment. Limnol Oceanogr 48: 1358-1369

Pedersen H, Lomstein BA, Blackburn TH (1993) Evidence for bacterial urea production in marine sediments. FEMS Microbiol Ecol 12:51-59

Peers GS, Milligan AJ, Harrison PJ (2000) Assay optimization and regulation of urease activity in two marine diatoms. J Phycol 36:523-528

Peierls BL, Paerl HW (1997) Bioavailability of atmospheric organic nitrogen deposition to coastal phytoplankton. Limnol Oceanogr 42:1819-1823

Perakis SS, Hedin LO (2002) Nitrogen loss from unpolluted South American forests mainly via dissolved organic com- pounds. Nature 415:416-419

Pettersen R (1975) Control by ammonium of intercompartmental guanine transport in Chlorella fusca. Z Pflanzenphysiol 76:213-223

Pettersen R, Knutsen G (1974) Uptake of guanine by synchronized Chlorella fusca: characterization of the transport system in autospores. Arch Microbiol 96:233-246

Petty RL, Michel WC, Snow JP, Johnson KS (1992) Determination of total primary amines in seawater and plant nectar with flow injection sample processing and fluorescence detection. Anal Chim Acta 142:299-304

Pintner IJ, Provasoli L (1963) Nutritional characteristics of some chrysomonads. In: Oppenheimer $\mathrm{CH}$ (ed) Symposium on Marine Microbiology. Thomas, Springfield, IL, p $114-121$

Poulet SA, Martin-Jezequel V (1983) Relationships between dissolved free amino acids, chemical composition and growth of the marine diatom Chaetoceros debile. Mar Biol 77:93-100

Price N, Harrison P (1987) Comparison of methods for the analysis of dissolved urea in seawater. Mar Biol 94: $307-317$

Price NM, Harrison PJ (1988) Urea uptake by Sargasso Sea phytoplankton: saturated and in situ uptake rates. DeepSea Res 35:1579-1593

Probyn TA (1985) Nitrogen uptake by size-fractionated phytoplankton populations in the southern Benguela upwelling systems. Mar Ecol Prog Ser 22:249-258

Pujo-Pay M, Conan P, Raimbault P (1997) Excretion of dissolved organic nitrogen by phytoplankton assessed by wet oxidation and ${ }^{15} \mathrm{~N}$ tracer procedures. Mar Ecol Prog Ser 153:99-111

Qafaiti M, Stephens GC (1988) Effect of nitrogen deprivation on amino acid uptake by chlorophyte Platymonas subcordiformis. Mar Biol 100:515-523

Raimbault P, Slawyk G, Boudjellal B, Coatanoan C and 5 others (1999) Carbon and nitrogen uptake and export in the equatorial Pacific at $150^{\circ} \mathrm{W}$ : evidence for an efficient regenerated production cycle. J Geophys Res 104: 3341-3356

Remsen CC, Carpenter EJ, Schroeder BW (1972) Competition for urea among estuarine microorganisms. Ecology 53: 921-926

Rich J, Gosselin M, Sherr E, Sherr B, Kirchman DL (1997) High bacterial production, uptake and concentrations of dissolved organic matter in the Central Arctic ocean. Deep-Sea Res II 44:1645-1663

Richards L, Thurston CF (1980) Uptake of leucine and tyrosine and their intracellular pools in Chlorella fusca var. vacuolata. J Gen Microbiol 121:39-47

Ricketts TR (1988) Homeostasis in nitrogenous uptake/assimilation by the green alga Platymonas (Tetraselmis) stiata (Prasinophyceae). Ann Bot 61:451-458

Riegman R, Noordeloos AAM (1998) Size-fractionated uptake of nitrogenous nutrients and carbon by phytoplankton in the North Sea during summer 1994. Mar Ecol Prog Ser 173:95-106

Riemann B, Jørgensen NOG, Lampert W, Fuhrman JA (1986) Zooplankton induced changes in dissolved free amino acids and in production rates of freshwater bacteria. Microb Ecol 12:247-258

Rondell JB, Finster KW, Lonstein BA (2000) Urea and DON uptake by Lyngbya gracialis dominated microbial mat: a controlled laboratory experiment. Aquat Microb Ecol 21: 169-175

Rosenstock B, Simon M (1993) Utilization of dissolved combined and free amino acids by planktonic bacteria in Lake 
Constance. Limnol Oceanogr 38:1521-1531

Rosenstock B, Simon M (2001) Sources and sinks of dissolved free amino acids and protein in a large and deep mesotrophic lake. Limnol Oceanogr 46:644-654

Russell KM, Galloway JN, Macko SA, Moody JL, Scudlark JR (1998) Sources of nitrogen in wet deposition to the Chesapeake Bay region. Atmos Environ 32:2453-2465

Saijo Y, Mitamura O, Ogiyama K (1974) Chemical composition of surface films in the coastal sea area and in freshwater lakes. Jpn J Limnol 35:110-116

Sakamoto T, Bryant DA (2001) Requirement of nickel as an essential micronutrient for the utilization of urea in the marine cyanobacterium Synechococcus sp. PCC 7002. Microbes Environ 16:177-184

Sakano S, Kamatani A (1992) Determination of dissolved nucleic acids in seawater by the fluorescence dye, ethidium bromide. Mar Chem 37:239-255

Sanders R, Jickells T (2000) Total organic nutrients in Drake Passage. Deep-Sea Res I 47:997-1014

Satoh Y, Okino T, Aoyama K (1980) Correlation between urea and other chemical and biological parameters in waters of Lake Suwa, Japan. Int Rev Gesamten Hydrobiol 65: $445-454$

Savidge G, Hutley HT (1977) Rates of remineralization and assimilation of urea by fractionated plankton populations in coastal waters. J Exp Mar Biol Ecol 28:1-16

Savidge G, Johnston JP (1987) Urea degradation rates by size-fractionated plankton populations in a temperate estuary. Estuar Coast Shelf Sci 24:433-447

Schnitzer M (1985) Nature of nitrogen in humic substances. In: Aiken GR, McKnight DM, Wershaw RL (eds) Humic substances in soil, sediment, and water. John Wiley \& Sons, New York, p 303-328

Schuster S, Arrieta JM, Herndl GJ (1998) Adsorption of dissolved free amino acids on colloidal DOM enhances colloidal DOM utilization but reduces amino acid uptake by orders of magnitude in marine bacterioplankton. Mar Ecol Prog Ser 166:99-108

Scudlark JR, Russell KM, Galloway JN, Church TM, Keene WC (1998) Organic nitrogen in precipitation at the MidAtlantic US Coast - methods evaluation and preliminary measurements. Atmos Environ 32:1719-1728

Seitzinger SP, Sanders R (1997) Contribution of dissolved organic nitrogen from rivers to estuarine eutrophication. Mar Ecol Prog Ser 159:1-12

Seitzinger SP, Sanders R (1999) Atmospheric inputs of dissolved organic nitrogen stimulate estuarine bacteria and phytoplankton. Limnol Oceanogr 44:721-730

Seitzinger SP, Sanders RW, Styles R (2002) Bioavailability of DON from natural and anthropogenic sources to estuarine plankton. Limnol Oceanogr 47:353-366

Sharp JH (1973) Total organic carbon in seawater-comparison of measurements using persulfate oxidation and high temperature combustion. Mar Chem 1:211-229

Sharp JH, Rinker KR, Savidge KB, Abell J and 23 others (2002) A preliminary methods comparison for measurement of dissolved organic nitrogen in seawater. Mar Chem 78:171-184

Shaw RD, Trimbee M, Minty A, Fricker H, Prepas EE (1989) Atmospheric deposition of phosphorus and nitrogen in central Alberta with emphasis on Narrow Lake. Water Air Soil Pollut 43:119-134

Shaw PJ, Chapron C, Purdie DA, Rees AP (1998) Impacts of phytoplankton activity on dissolved nitrogen fluxes in the tidal reaches and estuary of the Tweed, UK. Mar Pollut Bull 37:280-294

Simon M (1991) Isotope dilution of intracellular amino acids as a tracer of carbon and nitrogen sources of marine planktonic bacteria. Mar Ecol Prog Ser 74:295-301

Simon M (1998) Bacterioplankton dynamics in a large mesotrophic lake. II. Concentrations and turnover of dissolved amino acids. Arch Hydobiol 144:1-23

Simon M, Rosenstock B (1992) Carbon and nitrogen sources of planktonic bacteria in Lake Constance studied by the composition and isotope dilution of intracellular amino acids. Limnol Oceanogr 37:1496-1511

Simon M, Bunte C, Schultz M, Weiss M, Wunsch C (1998) Bacterioplankton dynamics in Lake Constance (Bodensee): substrate utilization, growth control and long term trends. Arch Hydrobiol Spec Issues Adv Limnol 53: 195-221

Siuda W, Chrost RJ (2000) Concentration and susceptibility of dissolved DNA for enzyme degradation in lake watersome methodological remarks. Aquat Microb Ecol 21: 195-201

Siuda W, Güde H (1996a) Determination of dissolved deoxyribonucleic acid concentration in lake water. Aquat Microb Ecol 11:193-202

Siuda W, Güde H (1996b) Evaluation of dissolved DNA and nucleotides as a potential source of phosphorus for plankton organisms in Lake Constance. Arch Hydrobiol 48: $155-162$

Slawyk G, Raimbault P (1995) Simple procedure for simultaneous recovery of dissolved inorganic and organic nitrogen in ${ }^{15} \mathrm{~N}$-tracer experiments and improving the isotopic mass balance. Mar Ecol Prog Ser 124:289-299

Slawyk G, Raimbault P, Garcia N (2000) Use of ${ }^{15} \mathrm{~N}$ to measure dissolved organic nitrogen release by marine phytoplankton. Limnol Oceanogr 45:1884-1886

Smith DC, Simon M, Alldredge AL, Azam F (1992) Intense hydrolytic enzyme activity on marine aggregates and implications for rapid particle dissolution. Nature 359: 139-142

Smith SV, Hollibaugh JT, Dollan SJ, Vink S (1991) Tomales Bay metabolism: C-N-P stoichiometry and ecosystem heterotrophy at the land-sea interface. Estuar Coast Shelf Sci 33:223-257

Soldo AT, Van Wagtendonk WJ (1961) Nitrogen metabolism in Paramecium aurelia. J Protozoology 8:41-55

Soldo AT, Godoy GA, Larin F (1978) Purine excretory nature of refractile bodies in the marine silicate Paramecium aurelia. J Protozoology 25:416-418

Steidinger KA, Vargo GA, Tester PA, Tomas CR (1998) Bloom dynamics and physiology of Gymnodinium breve with emphasis on the Gulf of Mexico. In: Anderson DM, Cembella AD, Hallegraeff GM (eds) Physiological ecology of harmful algal blooms. Springer-Verlag, Heidelberg, p 133-153

Steinberg C (1977) Schwerabbaubare, stickstoffhaltige gelijste organische Substanzen in Schijhsee und in Algenkulturen. Arch Hydrobiol (Suppl) 53:48-158

Stepanauskas R, Edling H, Tranvik LJ (1999a) Differential dissolved organic nitrogen availability and bacterial amino-peptidase activity in limnic and marine waters. Microb Ecol 38:264-272

Stepanauskas R, Leonardson L, Tranvik LJ (1999b) Bioavailablility of wetland-derived DON to freshwater and marine bacterioplankton. Limnol Oceanogr 44:1477-1485

Stepanauskas R, Laudon H, Jørgensen NOG (2000) High DON bioavailablility in boreal streams during a spring flood. Limnol Oceanogr 45:1298-1307

Stepanauskas R, Jørgensen NOG, Eigaard OR, Zvikas A (2002) Riverine nutrients in the Baltic Sea; bioavailability and eutrophication relevance. Ecol Monogr 72:579-598 
Sundh I (1992) Biochemical composition of dissolved organic carbon derived from phytoplankton and used by heterotrophic bacteria. Appl Environ Microbiol 58:2938-2947

Sutherland IW (1985) Biosynthesis and composition of gramnegative bacterial extracellular and wall polysaccharides. Annu Rev Microbiol 39:243-270

Suzuki S, Kogure K, Tanoue E (1997) Immunochemical detection of dissolved proteins and their source bacteria in marine environments. Mar Ecol Prog Ser 158:1-9

Suzuki Y, Sugimura Y (1985) A catalytic oxidation method for the determination of total nitrogen dissolved in seawater. Mar Chem 16:83-97

Takahashi M (2001) Nitrogen Metabolism. In: Saijo Y, Hayashi H (eds) Lake Kizaki: limnology and ecology of a Japanese lake. Backhuys, Leiden, p 123-138

Takahashi M, Saijo Y (1981) Nitrogen metabolism in Lake Kizaki, Japan. II. Distribution and decomposition of organic nitrogen. Arch Hydrobiol 92:359-376

Tamminen T, Irmisch A (1996) Urea uptake kinetics of a midsummer planktonic community on the SW coast of Finland. Mar Ecol Prog Ser 130:201-211

Tamminen T, Seppälä J (1999) Nutrient pools, transformations, ratios, and limitations in the Gulf of Riga, the Baltic Sea, during four successional stages. J Mar Systems 23: 83-106

Tanoue E (1995) Detection of dissolved protein molecules in oceanic waters. Mar Chem 51:239-252

Tanoue E, Nishiyama S, Kamo M, Tsugita A (1995) Bacterial membranes: possible source of a major dissolved protein in seawater. Geochim Cosmochim Acta 59:2643-2648

Tanoue E, Ishii M, Midorikawa T (1996) Discrete dissolved and particulate proteins in oceanic waters. Limnol Oceanogr 41:1334-1343

Theil $\mathrm{T}$ (1988) Transport of leucine in the cyanobacterium Anabaena variabilis. Arch Microbiol 149:466-470

Therkildsen MS, Lomstein BA (1994) Seasonal variation in sediment urea turnover in a shallow estuary. Mar Ecol Prog Ser 109:77-82

Therkildsen MS, King GM, Lomstein BA (1996) Urea production and turnover in a shallow estuary. Mar Ecol Prog Ser 109:77-82

Therkildsen M, Isaksen MF, Lomstein BA (1997) Urea production by the marine bacteria Delaya venusta and Pseudomonas stutzeri grown in a minimal medium. Aquat Microb Ecol 13:213-217

Thomsen L, Jahmlich S (1998) An in situ experiment to investigate the modification of particulate matter and urea above a benthic sandy silt community in the Baltic Sea. Hydrobiologia 376:353-361

Timperley MH, Vigor-Brown RJ, Kawashima M, Ishigami M (1985) Organic nitrogen compounds in atmospheric precipitation: their chemistry and availability to phytoplankton. Can J Fish Aquat Sci 42:1171-1177

Townshed DW, Thomas M (2002) Springtime nutrient and phytoplankton dynamics on Georges Bank. Mar Ecol Prog Ser 228:57-74

Tranvik LJ, Sherr EB, Sherr BF (1993) Uptake and utilization of 'colloidal DOM' by heterotrophic flagellates in seawater. Mar Ecol Prog Ser 92:301-309

Tsugita A, Uchida T, Mewes HW, Atake T (1987) A rapid vapor-phase acid (hydrochloric acid and trifluoroacetic acid) hydrolysis for peptide and protein. J Biochem 102: 1593-1597

Tupas L, Koike I (1990) Amino acid and ammonium utilization by heterotrophic marine bacteria grown in enriched seawater. Limnol Oceanogr 35:1145-1155

Turk V, Rehnstam AS, Lundberg E, Hagstrøm (1992) Release

Editorial responsibility: Fereidoun Rassoulzadegan,

Villefranche-sur-Mer, France of bacterial DNA by marine nanoflagellates, an intermediate step in phosphorus regeneration. Appl Environ Microbiol 58:3744-3750

Turner MF (1979) Nutrition of some marine microalgae with special reference to vitamin requirements and utilization of nitrogen and carbon sources. J Mar Biol Assoc UK 59: $535-552$

Valderrama JC (1981) The simultaneous analysis of total nitrogen and total phosphorus in natural waters. Mar Chem 10:109-122

Van Breemen N (2002) Natural organic tendency. Nature 415: 381-382

Vidal M, Duarte CM, Agusti S (1999) Dissolved organic nitrogen and phosphorus pools and fluxes in the central Atlantic Ocean. Limnol Oceanogr 44:106-115

Volk CJ, Volk CB, Kaplan LA (1997) Chemical composition of biodegradable organic matter in streamwater. Limnol Oceanogr 42:39-44

Waldron HN, Attwood CG, Probyn TA, Lucas MI (1995) Nitrogen dynamics in the Bellingshausen Sea during the Austral spring of 1992. Deep-Sea Res II 42:1253-1276

Walsh TW (1989) Total dissolved nitrogen in seawater: a new high temperature combustion method and a comparison with photo-oxidation. Mar Chem 29:295-311

Wang W, Tarr MA, Bianchi TS, Engelhaupt E (2000) Ammonium photoproduction from aquatic humic and colloidal matter. Aquat Geochem 6:275-292

Ward BB, Bronk DA (2001) Net nitrogen uptake and DON release in surface waters: importance of trophic interactions implied from size fractionation experiments. Mar Ecol Prog Ser 219:11-24

Weinbauer MG, Peduzzi P (1995a) Significance of viruses versus heterotrophic nanoflagellates for controlling bacterial abundance in the northern Adriatic Sea. J Plankton Res 17:1851-1856

Weinbauer MG, Peduzzi P (1995b) Effect of virus-rich high molecular weight concentrates of seawater on the dynamics of dissolved amino acids and carbohydrates. Mar Ecol Prog Ser 127:245-253

Wetzel RG (2001) Limnology: lake and river ecosystems. Academic Press, San Diego

Wheeler PA, Kirchman DL (1986) Utilization of inorganic and organic nitrogen by bacteria in marine systems. Limnol Oceanogr 31:998-1009

Wheeler PA, North BB, Stephens GC (1973) Amino acid uptake by marine phytoplankters. Limnol Oceanogr 19: 249-259

Wheeler PA, Watkins JM, Hansing RL (1997) Nutrients, organic carbon and organic nitrogen in the upper water column of the Arctic Ocean: implications for the sources of dissolved organic carbon. Deep-Sea Res II 44:1571-1592

Wiegner TN, Seitzinger SP (2001) Photochemical and microbial degradation of external dissolved organic matter inputs to rivers. Aquat Microb Ecol 24:27-40

Williams PJL (1993) Chemical and tracer methods of measuring plankton production. ICES Mar Sci Symp 197:20-36

Williams PJL, Berman T, Holm-Hansen O (1976) Amino acid uptake and respiration by marine heterotrophs. Mar Biol 35:41-47

Wiltshire KH, Lampert W (1999) A colony-inducing factor in Scenedesmus? Limnol Oceanogr 44:1894-1903

Zehr JP, Axler RP, Goldman CR (1985) Heterotrophic mineralization of amino acid nitrogen in subalpine Castle Lake, Calf. Mar Chem 16:343-350

Zehr JP, Paulsen SG, Axler RP, Goldman CR (1988) Dynamics of dissolved organic nitrogen in subalpine Castle Lake, California. Hydrobiologia 157:33-45

Submitted: August 26, 2002; Accepted: December 1, 2002

Proofs received from author(s): March 21, 2003 